Spatial debris-cover effect on the maritime glaciers

\title{
Spatial debris-cover effect on the maritime glaciers of Mount Gongga, south-eastern Tibetan Plateau
}

\section{Y. Zhang ${ }^{1,2}$, Y. Hirabayashi ${ }^{1}$, K. Fujita ${ }^{3}$, S. Liu $^{2}$, and Q. Liu ${ }^{4}$}

${ }^{1}$ Institute of Engineering Innovation, The University of Tokyo, 2-11-16 Yayoi, Bunkyo-ku, Tokyo 113-8656, Japan

${ }^{2}$ State Key Laboratory of Cryospheric Sciences, Cold and Arid Regions Environmental and Engineering Research Institute, Chinese Academy of Sciences, Lanzhou 730000, China ${ }^{3}$ Graduate School of Environmental Studies, Nagoya University, Chikusa-ku, Nagoya 464-8601, Japan

${ }^{4}$ Institute of Mountain Hazards and Environment, Chinese Academy of Sciences, Chengdu 610041, China

Received: 8 February 2013 - Accepted: 21 May 2013 - Published: 6 June 2013

Correspondence to: Y. Zhang (zhyong@sogo.t.u-tokyo.ac.jp)

Published by Copernicus Publications on behalf of the European Geosciences Union.

\section{Y. Zhang et al.}

Title Page
Full Screen / Esc

Printer-friendly Version 


\section{Abstract}

The Tibetan Plateau and surroundings contain a large number of debris-covered glaciers, on which debris cover affects glacier response to climate change by altering ice melting rates and spatial patterns of mass loss. Insufficient spatial distribution of

5 debris thickness data makes it difficult to analyze regional debris-cover effects. Mount Gongga glaciers, maritime glaciers in the south-eastern Tibetan Plateau, are characterized by a substantial reduction in glacier length and ice mass in recent decades. Advanced Spaceborne Thermal Emission and Reflection Radiometer (ASTER)-derived thermal property of the debris layer reveals that $68 \%$ of the glaciers have extensive which the proportion of debris cover to total glacier area varies from $1.74 \%$ to $53.0 \%$. Using a surface energy-mass balance model accounting for the debris-cover effect applied at a regional scale, we find that although the presence of supraglacial debris has a significant insulating effect on heavily debris-covered glaciers, it accelerates ice melting on $\sim 10.2 \%$ of the total 15 ablation area and produces rapid wastage of $\sim 25 \%$ of the debris-covered glaciers, resulting in the similar mass losses between debris-covered and debris-free glaciers. Widespread debris cover also facilitates the development of active terminus regions. Regional differences in the debris-cover effect are apparent, highlighting the importance of debris cover for understanding glacier status and hydrology in both the Tibetan Plateau and other mountain ranges around the world.

\section{Introduction}

The Tibetan Plateau and surroundings contain massive glaciers with a total area of approximately $116180 \mathrm{~km}^{2}$ (Dyurgerov and Meier, 2005) which are a vital source of water at the headwaters of many prominent Asian rivers (Immerzeel et al., 2010; Kaser et al., 2010). Mass changes of these glaciers and their response to climate change are of substantial importance for the evolution of water resources (Immerzeel et al., 2010;
TCD

$7,2413-2453,2013$

Spatial debris-cover effect on the maritime glaciers

Y. Zhang et al.

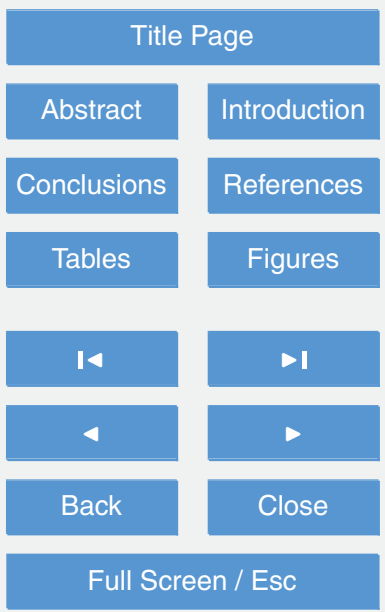

Printer-friendly Version

Interactive Discussion 
Kaser et al., 2010), although systematic differences in such response are apparent from region to region across the plateau because of heterogeneous climate forcing in the Tibetan Plateau and surroundings (Fujita, 2008; Fujita and Nuimura, 2011; Yao et al., 2012). In particular, the responses of debris-covered glaciers to climate change 5 are considerably more complex than those of debris-free glaciers (Scherler et al., 2011; Benn et al., 2012), because the debris-cover effect accelerates (if debris is thin) or suppresses (if it is thick) ice melting beneath debris relative to that of exposed snow and ice (Østrem, 1959; Nakawo and Young, 1981; Mattson et al., 1993; Kayastha et al., 2000). Furthermore, debris-covered glaciers are widespread in the Tibetan Plateau 10 and surroundings and generally contain a large ice volume (Paul et al., 2004; Scherler et al., 2011; Benn et al., 2012). Consequently, glacier response to climate forcing due to debris cover can be expected to exert a significant influence on the regional-scale evolution of river discharge and water resources. Realistic prediction of future water availability and its impacts in the Tibetan Plateau and surroundings, therefore, should consider the debris-cover effect that has influenced mass balance and runoff by altering both rates and spatial patterns of melting. Developing a better understanding of the role of debris cover in glacier status and hydrology at a regional scale nevertheless remains a challenge, as it will require an ensemble of estimate the extent and thickness of debris cover coupled with a large-scale mass-balance model accounting for the significance and effects of debris cover.

Part of the difficulty in such a study arises from poor knowledge of the large-scale spatial distribution of debris thickness and properties because of the practical difficulties of measuring debris thickness and properties on glaciers and methods for supraglacial debris satellite mapping remaining in development (e.g. Paul et al., 2004; 25 Suzuki et al., 2007; Mihalcea et al., 2008; Racoviteanu et al., 2009; Casey et al., 2012). Although several recent investigations have addressed the impact of debris cover on glacier status and runoff at a large scale (e.g. Lambrecht et al., 2011; Mayer et al., 2011; Scherler et al., 2011; Anderson and Mackintosh, 2012; Immerzeel et al., 2012), these studies relied on simplified representations of the extent and thickness of debris

Spatial debris-cover effect on the maritime glaciers

Y. Zhang et al.

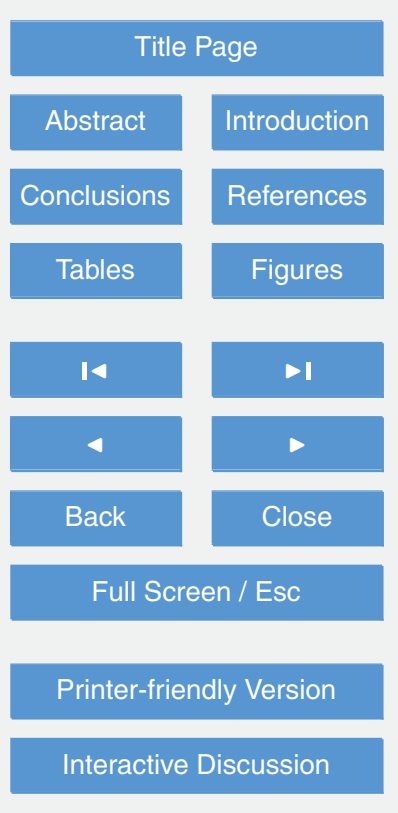

Interactive Discussion 
cover on the glaciers. Furthermore, several numerical models have been proposed (e.g. Kayastha et al., 2000; Nicholoson and Benn, 2006; Reid and Brock, 2010), but their application has mainly relied on high-quality input parameters related to the extent, thickness and thermal properties of debris cover. Consequently, an understanding of 5 where debris cover and its spatial distribution enhance or inhibit ice melt rates to modify its spatial characteristics and to what extent melting influences mass balance and runoff remains limited.

In this study, we attempt to determine the spatial distribution of debris cover throughout the ablation zones of the maritime glaciers of Mount Gongga, south-eastern Tibetan

10 Plateau, which is one of the largest and most sensitive remaining areas of maritime glaciers (Shi and Liu, 2000), based on field and remote-sensing based measurements. Using a surface energy-mass balance model that accounts for the significance of debris cover and its effects, we systematically discuss the potential influences of debris cover and its spatial distribution characteristics on the average status of the Mount 15 Gongga maritime glaciers at a regional scale and analyze the potential causes of regional differences in the debris-cover effect. Such work presents an integrated view of the debris-cover effect at a regional scale, which is a necessary first step toward understanding the response of debris-covered maritime glaciers to climate change and their impacts on the evolution of river discharge and water resources.

\section{Study area and data}

\subsection{Study area}

Mount Gongga $\left(29^{\circ} 20^{\prime}-30^{\circ} 10^{\prime} \mathrm{N}, 101^{\circ} 30^{\prime}-102^{\circ} 10^{\prime} \mathrm{E}\right.$; Fig. 1$)$ is located on the southeastern margin of the Tibetan Plateau, where the climate is characterized by the East Asian monsoon in the summer and the westerly circulation in the winter ( $\mathrm{Li}$ and $\mathrm{Su}$, 25 1996). Very few meteorological stations are operating in the region (Fig. 1), resulting in significant climatic uncertainties, especially in the magnitude of precipitation at

Spatial debris-cover effect on the maritime glaciers

Y. Zhang et al.

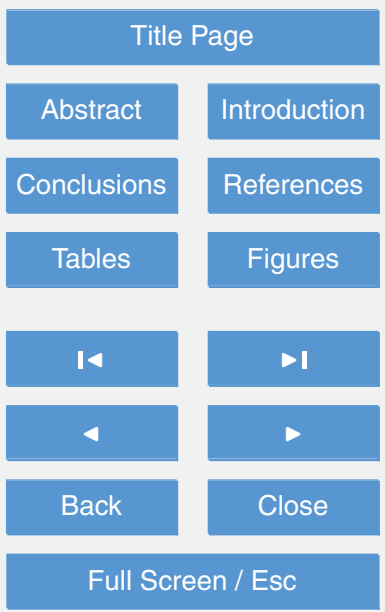

Printer-friendly Version

Interactive Discussion

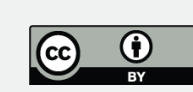


high elevations. Data from the Gongga Alpine Ecosystem Observation and Research Station (hereafter, GAEORS) located near the terminus of Hailuogou (HLG) Glacier (3000 ma.s.l.; Fig. 1) show that the mean annual air temperature and precipitation are $4.1^{\circ} \mathrm{C}$ and $\sim 1.9 \mathrm{~m}$ water equivalent (w.e.), respectively, for the period 1988-2004

5 (Zhang et al., 2010). Previous studies presented evidence for a warming trend in this region (Su et al., 1992; Liu et al., 2010; Zhang et al., 2010, 2012; Pan et al., 2012), with an increase of $0.13^{\circ} \mathrm{C}$ per decade between 1952 and 2009 (Zhang et al., 2012).

Mount Gongga contains 74 monsoonal maritime glaciers with an area of $257.7 \mathrm{~km}^{2}$ and a volume of $24.65 \mathrm{~km}^{3}$ measured from aerial photographs acquired in the $1960 \mathrm{~s}$ $10 \mathrm{Pu}, 1994)$. These glaciers belong to the summer-accumulation type, gaining mass mainly from summer-monsoon snowfall (Li and Su, 1996; Shi and Liu, 2000). Glacier equilibrium-line altitudes (ELAs) vary between 4800 and 5240 ma.s.I. (Pu, 1994; $\mathrm{Li}$ and Su, 1996). Five glaciers, including HLG Glacier, Mozigou (MZG) Glacier, Yanzigou (YZG) Glacier, Nanmenguangou (NMGG) Glacier and Dagongba (DGB) 15 Glacier (Fig. 1), have a length greater than $10 \mathrm{~km}$ and together account for $68.4 \%$ of total ice volume (Table 1). Many of these glaciers have considerable surface debris cover in their ablation zones, a consequence of the steep rocky terrain and mixed ice/snow/rock avalanche activities occurring on the surrounding walls through frost weathering processes and structural rockfalls (Li and Su, 1996).

$20 \quad$ Mount Gongga glaciers have a high ice velocity (Song, 1994; Li and Su, 1996; Zhang et al., 2010), with maximum velocities in the order of $>200 \mathrm{~m} \mathrm{yr}^{-1}$ (Song, 1994; Zhang et al., 2010). Most glaciers on Mount Gongga have experienced considerable terminus retreat and mass loss since the early 20th century (Su et al., 1992; Liu et al., 2010; Zhang et al., 2010, 2012; Pan et al., 2012).

Spatial debris-cover effect on the maritime glaciers

Y. Zhang et al.

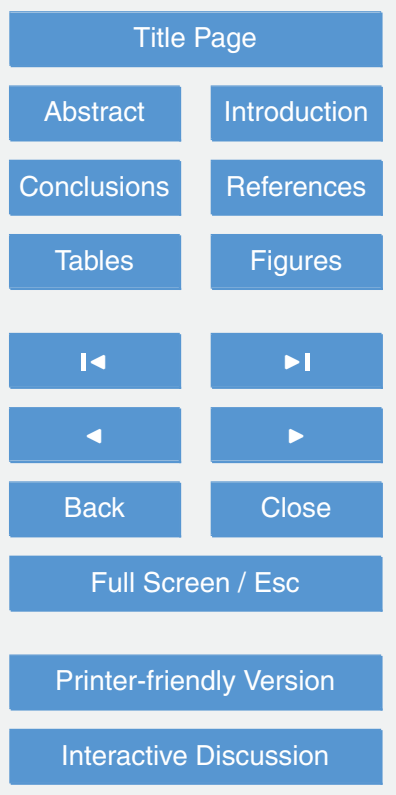




\subsection{Data}

\subsubsection{ASTER data}

Four orthorectified images of the Terra Advanced Spaceborne Thermal Emission and Reflection Radiometer (ASTER), obtained on 17 December 2008 and 18 January 2009

5 (11.58 a.m. LT), were used for determining the spatial distribution of debris cover and its property. There is no cloud or snow cover in these images. Two images were generated and distributed as Level 3A01 products by the ASTER Ground Data System (ASTER GDS) at the Earth Remote Sensing Data Analysis Center (ERSDAS) in Japan (ERSDAC, 2002; Fujisada et al., 2005). The geography location of these images was affine-transformed by referring to a topographical map, and the root mean square error of the affine transformation was within $15 \mathrm{~m}$ (Zhang et al., 2010). The other two images were generated and distributed by the ASTER Grid system of the Global Earth Observation Grid (GEO Grid; http://docs.geogrid.org/TechDocs/ASTERDataBeta). Details of the ASTER Grid system of GEO Grid can be found in Sekiguchi et al. (2008). ASTER measures three visible and near infrared bands (VNIR, 0.4-0.9 $\mu \mathrm{m}$ ) at a $15 \mathrm{~m}$ spatial resolution, six shortwave infrared bands (SWIR, 1.0-2.5 $\mathrm{m}$ ) at a $30 \mathrm{~m}$ spatial resolution, and five thermal infrared bands (TIR, 3.0-12 $\mu \mathrm{m}$ ) at a $90 \mathrm{~m}$ spatial resolution. In this study, we used the ASTER VNIR and TIR bands.

\subsubsection{Meteorological data}

20 To drive the detailed surface energy-mass balance model used in this study, we used various meteorological datasets, including daily data for air temperature, precipitation, wind speed and relative humidity observed at GAEORS (Fig. 1) for the period 19882007 , and observation-based global $0.5^{\circ}$ gridded data of daily precipitation and nearsurface temperature from the closest grid of the region for the period 1951-2007. In addition, air temperature and precipitation data observed at an automatic weather station (AWS; 3550 m a.s.I.) and a precipitation gauge (3500 $\mathrm{m}$ a.s.l.) installed in the HLG

Spatial debris-cover effect on the maritime glaciers

Y. Zhang et al.

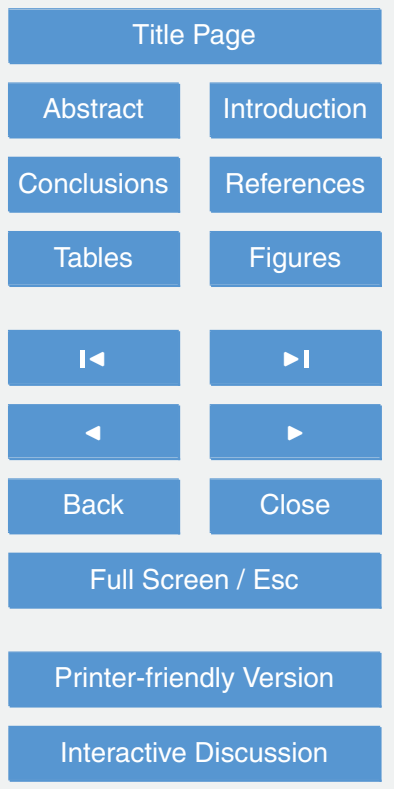

Interactive Discussion 
catchment (Fig. 1) were used for analyzing the meteorological conditions during the image acquisition days.

The gridded temperature dataset was generated by Hirabayashi et al. (2008) based on monthly temperature values of the Climate Research Unit version TS 2.1 dataset

5 for the period 1951-2002 (CRU; Mitchell and Jones, 2005) and the dataset of Fan and van den Dool (2008) for the period 2003-2007, whereas the daily precipitation dataset was created by collecting and analyzing rain-gauge observation data across Asia, an only long-term continental-scale high-resolution daily product that contains a dense network of daily rain-gauge data for Asia including the Himalayas and mountainous 10 areas in the Middle East (Yatagai et al., 2009). Full details of the global gridded temperature and precipitation datasets and their generation methods can be found in the work of Hirabayashi et al. (2008) and Yatagai et al. (2009), respectively. The altitude information of the grid cell was derived from the 30 arc s elevation data of the Shuttle Radar Topography Mission (http://dds.cr.usgs.gov/srtm/version2_1/SRTM30/).

15 The global gridded data of precipitation and near-surface temperature were biascorrected on a daily timescale by Zhang et al. (2012) using linear regression equations established between the observations from GAEORS and the global gridded data over the period 1988-1997. Also, the ability of the bias-corrected global gridded data to drive the surface energy-mass balance model was verified in the HLG catchment (Fig. 1), which indicates that the bias-corrected data correspond sufficiently well with the observations at GAEORS to be used as input for the energy-mass balance model (Zhang et al., 2012).

\subsubsection{Debris thickness and ablation data}

The first in situ measurements of debris thickness and ablation on Mount Gongga glaciers was carried out in 1982 at 23 sites on HLG Glacier, 19 sites on DGB Glacier and 11 sites on Xiaogongba (XGB) Glacier (Li and Su, 1996). Systematic debris thickness measurements were made at more than 300 sites across the entire ablation zone of HLG Glacier in 2009, and ice ablation data were collected during the summer of

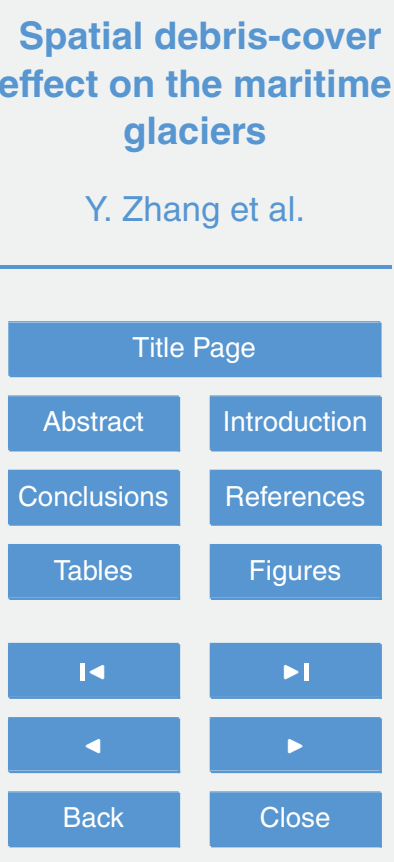

Full Screen / Esc

Printer-friendly Version 
2008 using 27 ablation stakes drilled into the glacier at different elevations (Zhang et al., 2011), which were used to analyze the effect of various debris thicknesses on ice melt rates.

\subsubsection{Glacier outline and ELA data}

5 Mount Gongga glacier outlines in 1966 and 2009 were used for estimating area and terminus changes of glaciers. The glacier outline for 1966, from the Chinese Glacier Inventory (CGl; Pu, 1994), was interpreted and measured by stereophotogrammetry from aerial photographs acquired in the 1960s and corrected by aerial photographs and field investigations (Pu, 1994). The error in glacial extent estimates of the CGI varies from $\pm 0.5 \%$ to $\pm 1 \%(\mathrm{Pu}, 1994)$. The glacier outline for 2009 was derived from Landsat MSS, TM, ETM+ and ASTER data using threshold ratio images, and was verified by GPS surveys on different glaciers in 2009 (Pan et al., 2012). The results of the surveys indicate that there is about $\pm 30 \mathrm{~m}$ difference in the length and $0.5 \%$ error in the area (Pan et al., 2012). Full details of these data and their generation methods can be found in the work of Pan et al. (2012).

ELA data of Mount Gongga glaciers were used to determine the extents of ablation zones. Glacier ELAs recorded in the CGI (Pu, 1994) range from 4800 to 5240 ma.s.l. The average ELA is $\sim 4900$ ma.s.I. on the eastern slope and $\sim 5100$ ma.s.l. on the western slope of Mount Gongga (Su et al., 1992; Pu, 1994).

\subsubsection{Digital elevation model}

A DEM was produced from aerial photographs acquired in 1989 (Zhang et al., 2010). The accuracy of the DEM was validated by GPS data on glacier-free terrain, yielding a root mean square error of $11.2 \mathrm{~m}$ (Zhang et al., 2010). The DEM was resampled to $90 \mathrm{~m}$ for use by the model.

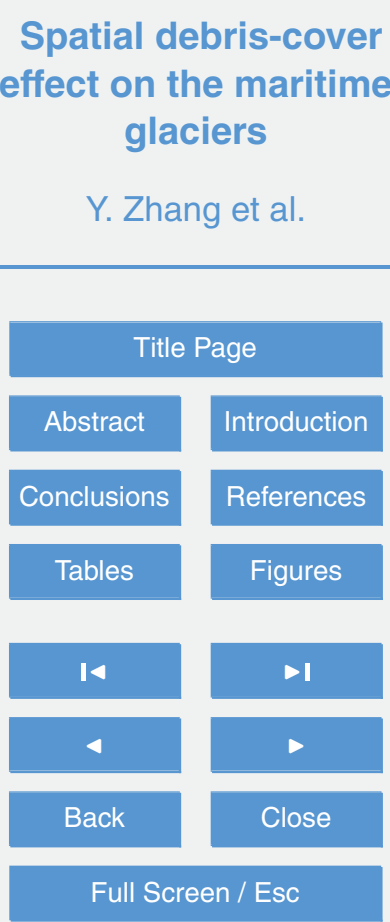

Printer-friendly Version

Interactive Discussion 


\section{Methods}

\subsection{Glacier discretization and data preprocessing}

Glaciers on Mount Gongga were divided into a set of elevation bands at intervals of $50 \mathrm{~m}$ based on the DEM and glacier outlines. The area of each elevation band was obtained from the DEM based on the glacier outlines. The extent of each ablation zone was determined based on the DEM and glacier outlines combined with the distribution of ELAs, which we obtained from the CGI (Pu, 1994). In addition, the aspect of each glacier was measured from the DEM, and the mean slope of the ice surface in the ablation zones of Mount Gongga glaciers was measured along the profiles that follow the central flowline (lowermost 1-2 km, depending on glacier size).

The air temperature and precipitation time series were interpolated for each elevation band according to its mean elevation. The air temperature decreased with increasing altitude with a constant lapse rate (Table 2), and precipitation increased linearly with increasing altitude with a precipitation gradient (\% of precipitation increase per meter of elevation increase; Table 2) from the snout to the top of the glacier. Wind speed observed from GAEORS was not interpolated and assumed constant across the glacier surface (Zhang et al., 2012).

\subsection{Thermal resistance of a debris layer}

The thermal resistance of a debris layer $\left(R ; \mathrm{m}^{2} \mathrm{~K} \mathrm{~W}^{-1}\right)$, defined as debris thickness divided by the thermal conductivity of the debris layer (Nakawo and Young, 1981, 1982), is expressed as

$R=\frac{h}{\lambda}$,

where $h$ and $\lambda$ are the thickness $(\mathrm{m})$ and the thermal conductivity $\left(\mathrm{Wm}^{-1} \mathrm{~K}^{-1}\right)$ of the debris layer, respectively. Note that field determinations of the thickness and thermal

Spatial debris-cover effect on the maritime glaciers

Y. Zhang et al.

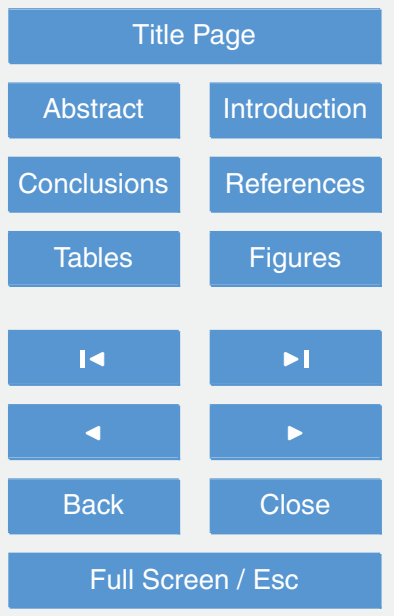

Printer-friendly Version

Interactive Discussion 
conductivity of the debris layer are especially time-consuming and unrealistic at a large scale. The thermal resistance of the debris layer in this study was therefore calculated from the surface temperature of the debris layer derived from ASTER TIR bands and the net radiation estimated from ASTER VNIR bands and US National Centers for En5 vironmental Prediction (NCEP)/US National Center for Atmospheric Research (NCAR) reanalysis data (Kalnay et al., 1996), which correspond to the nearest time and location of ASTER acquisition, with the assumption of negligible turbulent fluxes in the energy balance. The approach used in this study is identical to that used in previous studies (Suzuki et al., 2007; Zhang et al., 2011). The average brightness temperature 10 was retrieved from five TIR bands of ASTER and was used as the surface temperature on the glaciers, and the broadband albedo was estimated directly from the spectral reflectance at the top of the atmosphere in VNIR bands of ASTER. Combined with corresponding surface downward radiation fluxes from NCEP/NCAR reanalysis data we calculated the thermal resistances of debris layers over the ablation zones of the 15 Mount Gongga glaciers mentioned above (Fig. 2a). The pixel size of ASTER TIR image is $90 \mathrm{~m}$ and thermal resistance was calculated using this same resolution.

As investigations on HLG Glacier (Fig. 1) showed (Zhang et al., 2011), ASTERderived thermal resistances correlated reasonably well with ground-surveyed debris thicknesses over the entire ablation zone, and across- and along-glacier patterns of ASTER-derived thermal resistances correspond well with spatial patterns of groundsurveyed debris thicknesses, which can reflect large-scale variation in the extent and thickness of the debris cover and support the use of thermal resistance as a proxy for debris thickness over large areas. To assess the validity of applying thermal resistance as the proxy for debris thickness distribution on other debris-covered glaciers of this region, we compared along-glacier patterns of ground-surveyed debris thicknesses on DGB and XGB glaciers (Fig. 1) and ASTER-derived thermal resistances, which indicates that their variations agree reasonably well (Fig. 3). Therefore, we use the ASTER-derived thermal resistance as the proxy for the spatial distribution of debris thickness on the Mount Gongga glaciers.

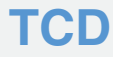

7, 2413-2453, 2013

Spatial debris-cover effect on the maritime glaciers

Y. Zhang et al.

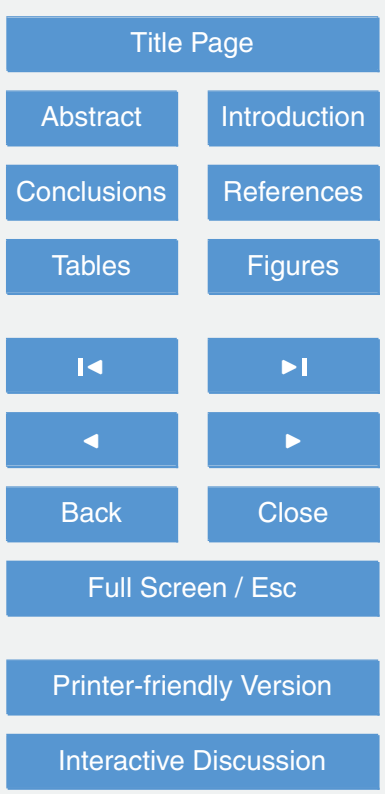




\subsection{Surface energy-mass balance model}

No systematic direct measurement of glacier mass balance exists for Mount Gongga, and only isolated measurements of melt rates on debris-covered ablation zones of DGB, XGB and HLG glaciers have been made (Li and Su, 1996; Zhang et al., 2011).

5 The mass balances of Mount Gongga glaciers were therefore estimated at intervals of $50 \mathrm{~m}$ altitude for the period 1998-2007 using a surface energy-mass balance model that can consider the debris-cover effect, and computed the area-averaged mass balance using the obtained area-altitude distribution of each glacier. The surface energy-mass balance model used in this study is identical to that developed by Zhang et al. (2012) and is described only briefly here. The model was verified by comparing model results to the observed runoff and glacier ablation in different periods in the HLG catchment (Fig. 1), one of the glacierized catchments on Mount Gongga (Zhang et al., 2012), which consists of two coupled components. The first is to compute the energy available for melting from energy exchange between the debris-covered/free surface 15 and the atmosphere, and accumulation. The second is to treat processes occurring in the subsurface after meltwater percolates in the underlying layers. The model calculates the surface mass balance for each elevation band at a time step of one day. Mass balance $(B)$ at any location on the glacier is calculated as

$B=\mathrm{Ca}+Q_{\mathrm{M}} / \rho_{\mathrm{i}} L_{\mathrm{f}}+E_{\mathrm{V}}+R_{\mathrm{F}}$,

where $\mathrm{Ca}$ (positive sign) is accumulation (snow), $R_{\mathrm{F}}$ (positive sign) is refreezing, $Q_{\mathrm{M}} / \rho_{\mathrm{i}} L_{\mathrm{f}}$ and $E_{\mathrm{V}}$ are ablation and evaporation (mass loss terms are defined negatively), respectively. All terms are in units of m w.e. $Q_{\mathrm{M}}, \rho_{\mathrm{i}}$ and $L_{\mathrm{f}}$ are energy available for melting, density of ice (Table 2) and latent heat of fusion (Table 2), respectively.

Accumulation is modelled from the precipitation value by using a simple temperature threshold to determine whether precipitation falls as rain from snow. A mixture of snow and rain is assumed for a transition zone ranging from $1 \mathrm{~K}$ above and $1 \mathrm{~K}$ below the threshold temperature (Table 2). The refreezing amount is calculated by considering

Spatial debris-cover effect on the maritime glaciers

Y. Zhang et al.

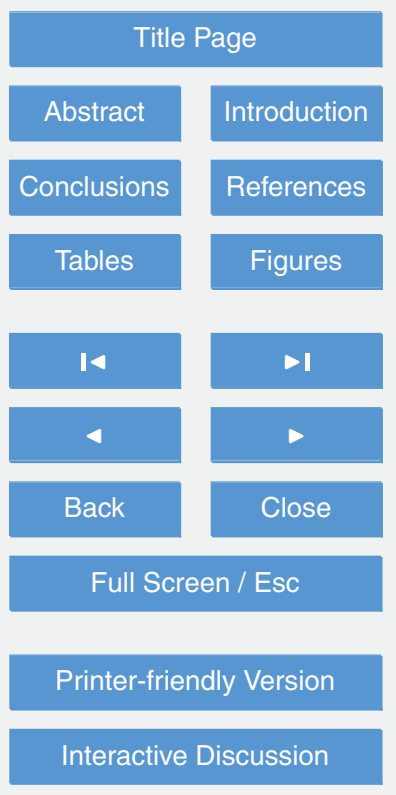

Interactive Discussion

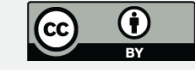


the conduction of heat into the snow layer and glacier ice and the presence of water at the interface between the snow layer and glacier ice (Fujita and Ageta, 2000). Refreezing during winter and during shorter cooling events is also considered. According to the spatial distribution of the thermal resistance of the debris cover ( $R$; Fig. 2a), glaciers 5 on Mount Gongga are classified as debris-covered $(R>0)$ and debris-free $(R \leq 0)$ surfaces. For the debris-free ice, the energy available for melting $\left(Q_{\mathrm{M}}\right)$ is calculated from

$Q_{\mathrm{M}}=(1-\alpha) R_{\mathrm{S}}+R_{\mathrm{Ld}}+R_{\mathrm{Lu}}+Q_{\mathrm{S}}+Q_{\mathrm{L}}+Q_{\mathrm{G}}$

where $R_{\mathrm{S}}, R_{\mathrm{Ld}}$ and $R_{\mathrm{Lu}}$ are the downward short-wave radiation flux, downward longwave radiation flux and upward long-wave radiation flux, respectively, $Q_{\mathrm{S}}, Q_{\mathrm{L}}$ and $Q_{\mathrm{G}}$ are the net sensible and latent heat fluxes and conductive heat flux into the glacier ice, respectively, and $\alpha$ is the surface albedo (Table 2). All terms are taken to be positive toward the surface in units of $\mathrm{Wm}^{-2}$.

For the debris-covered ice, the only heat flux considered to reach the glacier ice is the conductive heat flux with simplifying assumption of a linear temperature profile within the debris layer and the constant heat flux stored in the debris layer from day to day (Kraus, 1975; Nakawo and Young, 1981; Zhang et al., 2011). The energy available for melting $\left(Q_{\mathrm{M}}\right)$ is therefore calculated from

$$
\left\{\begin{array}{l}
\left(1-\alpha^{\prime}\right) R_{\mathrm{S}}+R_{\mathrm{Ld}}+R_{\mathrm{Lu}}+Q_{\mathrm{S}}+Q_{\mathrm{L}}+Q_{\mathrm{G}}^{\prime}=0 \\
Q_{\mathrm{M}}=Q_{\mathrm{G}}^{\prime}=\frac{T_{\mathrm{S}}-T_{1}}{R}
\end{array}\right.
$$

20 where $Q_{G}^{\prime}$ is the conductive heat flux into the debris layer, respectively, and $\alpha^{\prime}$ is the albedo of debris-covered surface, which is estimated using ASTER data. $T_{\mathrm{S}}$ is the surface temperature of the debris-covered surface $\left({ }^{\circ} \mathrm{C}\right)$, and $T_{1}$ is the surface temperature of the debris-ice interface, which was set to $0^{\circ} \mathrm{C}$ (Zhang et al., 2011).

The various components of the energy balance were calculated using climatic and 25 topographic data mentioned above. Absorbed short-wave radiation is calculated from the surface albedo and downward short-wave radiation, which is derived from daily

Spatial debris-cover effect on the maritime glaciers

Y. Zhang et al.

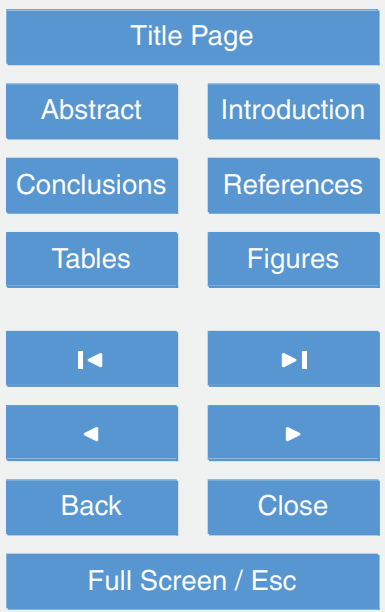

Printer-friendly Version

Interactive Discussion 
transmissivity estimated from daily precipitation using the relationship between the monthly means of precipitation and transmissivity and the incoming short-wave radiation at the top of the atmosphere (Zhang et al., 2012). Surface albedo, controlling the magnitude of absorption of short-wave radiation, is calculated using the method of 5 Fujita (2007), by which the albedo is calculated using a simplified concept of multiple scattering in an ice plate having thickness related to the surface snow density (which changes with snow compaction). Upward long-wave radiation is calculated using the Stefan-Boltzmann law, and downward long-wave radiation is obtained from air temperature, relative humidity and the ratio of downward short-wave radiation to that at the top of the atmosphere using an empirical scheme (Fujita and Ageta, 2000). Relative humidity before 1988 is calculated based on the relationship between the monthly means of precipitation and relative humidity established by Zhang et al. (2012). Sensible and latent turbulent heat fluxes are obtained by bulk methods. The surface temperature for debris-free surface is obtained to satisfy all heat balance equations by iterative calculation of the conductive heat flux, which is obtained by calculating the temperature profile of the snow layer and/or glacier ice. The surface temperature for debris-covered surface is calculated numerically by iteration with simplifying assumptions that the temperature profile within the debris layer is linear and the conductive heat flux at the debris surface is the same as that at the ice surface (Zhang et al., 2011, 2012).

\subsection{Melt ratio and glacier terminus changes}

To systematically and comprehensively assess the debris-cover effect on the icemelting pattern, a melt ratio (MR), defined as the sub-debris melt rate $(M)$ divided by the melt rate under the assumption of no debris in the same pixel $\left(M^{\prime}\right)$, is expressed as

$25 \quad \mathrm{MR}=\frac{M}{M^{\prime}}$
TCD

7, 2413-2453, 2013

Spatial debris-cover effect on the maritime glaciers

Y. Zhang et al.

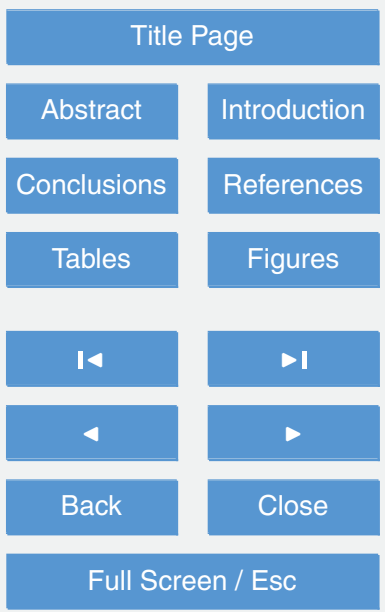

Printer-friendly Version

Interactive Discussion 
$M$ and $M^{\prime}$ are respectively calculated using Eqs. (4) and (3) and are averaged over the period 1952-2007. A melt ratio $>1.0$ means that the presence of debris enhances the ice melting (hereafter termed "accelerating effect" for simplicity), whereas a ratio $<1.0$ means that debris inhibits the ice melting (hereafter termed "insulating effect" for simplicity). A melt ratio of 1.0 indicates that the ice melt rate beneath the debris layer equals that of bare ice.

We measured changes in glacier area at the terminus from the glacier outlines of 1966 (Pu, 1994) and 2009 (Pan et al., 2012). Combined with glacier widths we calculated mean annual terminus advance or retreat rates for the period 1966-2009.

\section{Results}

\subsection{Spatial pattern of debris thermal properties}

The spatial distribution of ASTER-derived thermal resistance of the debris layer over the ablation zones of the Mount Gongga glaciers is shown in Fig. 2a. The Mount Gongga are classified as debris-covered and debris-free surfaces based on the spatial

distribution of the thermal resistance of the debris cover (Fig. 2a). Among 74 glaciers on Mount Gongga, 50 glaciers are covered with a varying thickness of debris (Fig. 2a). These glaciers represent $68.0 \%$ and $93.4 \%$ of the total glacier number and area of Mount Gongga. The proportion of debris cover to the total glacier area varies from $1.74 \%$ to $53.0 \%$. The total debris-covered area is $\sim 32 \mathrm{~km}^{2}$, accounting for as much as $13.5 \%$ of the total glacier area of the region (Fig. 1b). Debris covers most of the ablation zone below 3800 ma.s.l. (Fig. 1b), but the area of debris-covered surface across the elevation band between 3800 and 4800 m a.s.I. represents $82 \%$ of the total debriscovered area, and only $7 \%$ of the debris cover occurs above $4800 \mathrm{~m}$ a.s.I. In particular, debris cover predominantly occurs in the tongues of large valley glaciers, and the volume of debris-covered glaciers with an area $>5 \mathrm{~km}^{2}$ accounts for as much as $78.3 \%$ of the total glacier volume of Mount Gongga. Among the five glaciers with length $>10 \mathrm{~km}$

\section{Spatial debris-cover effect on the maritime glaciers \\ Y. Zhang et al.}

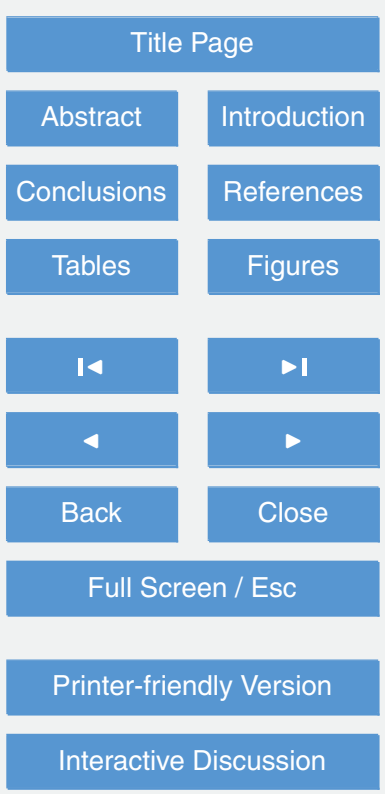


in the region (Table 1), NMGG Glacier (Fig. 1) has the largest debris cover, $~ 20.1 \%$ of the total glacier area, and HLG Glacier, the longest glacier on Mount Gongga, has $\sim 6.4 \%$ debris cover.

Figure 2a shows that relatively high values of thermal resistance are generally found 5 at the termini of glaciers and lower values occur mainly in the upper reaches of the ablation zones. Such a trend corresponds well with the observed spatial pattern of debris cover in the field, i.e. the debris cover is thick and continuous at the termini and is thin and patchy in the upper reaches of the ablation zones. Spatial patterns of ground-surveyed debris thicknesses (Fig. 3) and thermal resistances of debris layers 10 (Fig. 2a) on different glaciers all reveal the same variation trend of debris thickness, a downglacier increase, but considerably spatial variability exists at each site. Systematic debris thickness measurements on Mount Gongga have been made only on HLG Glacier and these indicates that debris emerges on the glacier surface below the icefall at $\sim 3600$ ma.s.I., from where its thickness increases to more than $1.0 \mathrm{~m}$ near the glacier terminus. According to in situ surveys of debris thickness on HLG Glacier (Fig. 3c), we find that the debris cover is thick in the altitude range of 2900$3100 \mathrm{~m}$ a.s.l., where its mean thickness is $\sim 0.4 \mathrm{~m}$, and the debris cover is thin in the altitude range of 3100-3600 m a.s.l., where its mean thickness is $\sim 0.09 \mathrm{~m}$. Of the in situ debris thickness measurements on the glacier, $~ 50.3 \%$ have a debris thickness of less than $0.1 \mathrm{~m}$ and $\sim 25 \%$ have a thickness of less than $0.03 \mathrm{~m}$. Debris thicknesses and ASTER-derived thermal resistances along transverse profiles, which were constructed across representative areas of HLG Glacier (terminus, central and upper parts of the ablation zone) (Zhang et al., 2011), indicate the considerably inhomogeneous distribution in space, especially at the profiles near the terminus where the debris thickness varies from a few centimeters to more than $1.0 \mathrm{~m}$.

No systematic direct measurement of debris thickness exists for Mount Gongga glaciers with the exception of HLG, DGB and XGB glaciers. We calculated the thermal resistance for $0.03 \mathrm{~m}$ debris layer based on the relationship between the debris thickness and thermal resistance, which is established using more than 300

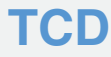

$7,2413-2453,2013$

Spatial debris-cover effect on the maritime glaciers

Y. Zhang et al.

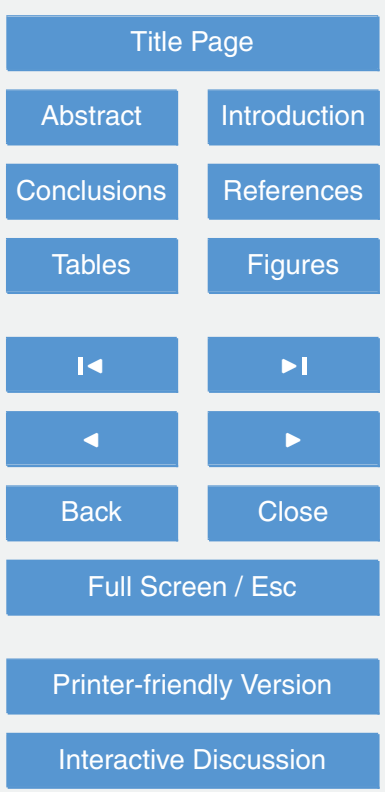


ground-surveyed debris thicknesses and corresponding ASTER-derived thermal resistances on HLG Glaciers (Zhang et al., 2011; Fig. 5). The calculated thermal resistance for $0.03 \mathrm{~m}$ debris layer is $1.34 \times 10^{-2} \mathrm{~m}^{2} \mathrm{KW}^{-1}$, and we found that $\sim 27 \%$ of the total debris-covered area on Mount Gongga glaciers has a thermal resistance value 5 smaller than it. As noted above, debris thickness revealed by the spatial distribution of ASTER-derived thermal resistances of debris layers (Fig. 2a) shows a significant inhomogeneous spatial distribution; in particular, the thin debris cover $<0.03 \mathrm{~m}$ is widely distributed on debris-covered glaciers on Mount Gongga.

\subsection{Debris-cover effects on Mount Gongga glaciers}

\subsubsection{Debris-cover effect on ice-melting pattern}

The spatial distribution of the melt ratio in the ablation zones of Mount Gongga glaciers is depicted in Fig. 2 b. About $10.2 \%$ of the total ablation area of debris-covered glaciers, where the melt ratio is $>1.0$, has experienced accelerated melting, $\sim 40.8 \%$ of the total ablation area, where the melt ratio is $<1.0$, has undergone inhibited melting, and $15 \sim 49 \%$ of the total ablation area has the melt ratio equal to 1.0 (Fig. $2 \mathrm{~b}$ ). Five glaciers in the region have lengths $>10 \mathrm{~km}$ and all of these have debris cover (Fig. 2). Their debris-covered proportions of total glacier area vary from $1.74 \%$ to $20.1 \%$ (Table 1). We observed only one of the five glaciers, HLG Glacier, which is characterized by significant accelerating effect of debris cover. About $44 \%$ of the ablation zone on HLG Glacier experiences accelerated melting, and $\sim 17 \%$ of the ablation zone experiences inhibited melting (Table 1). YZG Glacier, the largest glacier in the region, has $11.7 \%$ debris cover (Table 1), where accelerating and insulating effects of debris cover in the ablation zone are almost the same. The remaining three glaciers show significant insulating effect of debris cover in their ablation zones (Table 1).

According to in situ ablation measurements beneath various debris thicknesses on HLG, XGB and DGB glaciers, we found that debris thickness principally controls subdebris melt rates and its small change results in a marked change in the ice melt rate.
TCD

7, 2413-2453, 2013

Spatial debris-cover effect on the maritime glaciers

Y. Zhang et al.

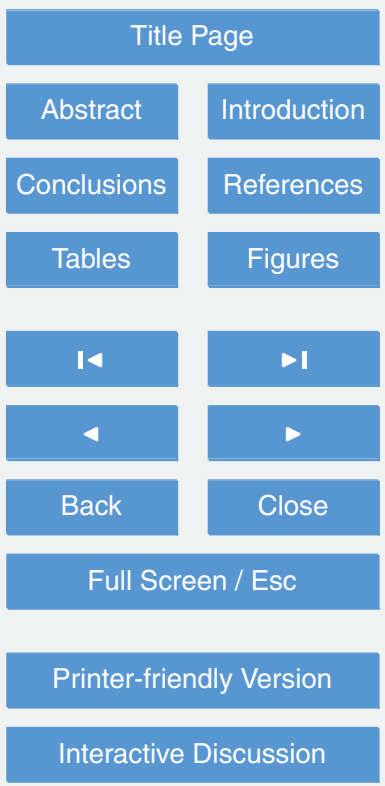


The mean debris thickness on DGB Glacier $(\sim 0.54 \mathrm{~m})$ is significantly larger than that on HLG Glacier ( $\sim 0.16 \mathrm{~m}$ ) (Fig. 3), a difference also revealed by the spatial distribution of thermal resistance (Fig. 2a), with the consequence that the two glaciers show opposite trends in the debris-cover effect (Table 1). As shown in Fig. 2a, debris-covered

5 glaciers on Mount Gongga have an apparently inhomogeneous distribution of debris thickness and widespread thin debris cover. Consequently, spatial differences in the debris-cover effect on the ice-melting pattern are apparent on these glaciers (Fig. 2b), making it completely different from the up-glacier decrease in the ablation gradient on debris-free glaciers. Such altered spatial patterns of melting will lead to significant 10 spatial variability in the regional ablation regime.

\subsubsection{Debris-cover effect on mass balance}

According to the calculation, most of the Mount Gongga glaciers have a negative mass balance for the period 1998-2007 with the mean annual mass balance of $-0.63 \mathrm{~m}$ w.e. As recent investigations showed (Liu et al., 2010; Zhang et al., 2010, 2012; Pan et al., 2012), temperature rise has contributed to glacier shrinkage on Mount Gongga, especially the summer temperature increase. Climatic conditions are the fundamental control on glacier mass balance variation (Oerlemans and Fortuin, 1992; Paterson, 1994), but this control is influenced by other factors, including glacier size, slope, aspect, elevation, debris cover or a combination of many factors (e.g. Scherler et al., 20 2011; Anderson and Mackintosh, 2012). Pan et al. (2012) discussed glacier changes with topographic factors (glacier size, aspect and slope) on Mount Gongga and did not find strong correlations between glacier retreat rates and topographic factors. The relationships between mean annual mass balances and glacier elevation, area, aspect and surface slope are illustrated in Fig. 4 along with proportions of debris cover. We find that these factors exert a significant influence on the mass balance of debriscovered glaciers. Nevertheless, Fig. 4 indicates that these factors are more weakly related to mass balance relative to debris cover. This phenomenon was also found on maritime glaciers in the Southern Alps of New Zealand, where no clear relationship

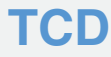

$7,2413-2453,2013$

Spatial debris-cover effect on the maritime glaciers

Y. Zhang et al.

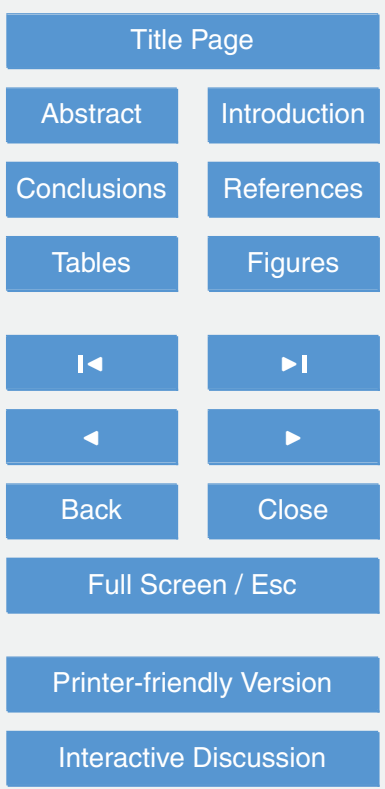


exists between mass balance sensitivity and topographic characteristics (aspect, slope and elevation) but a relationship does exist with debris cover (Anderson and Mackintosh, 2012). In general, negative mass balance is intensified with increasing debriscovered proportion at the same elevation, as well as at the same area, and at the same 5 aspect and surface slope (Fig. 4).

To comprehensively assess the impact of debris cover on the mass balance of the whole region, we recalculated the mean annual mass balance under the assumption of no debris cover on the debris-covered glaciers. A comparison of the mass balances under the plausibly real surface condition with those of the no-debris assumption in10 dicates that mass loss is accelerated on $\sim 25 \%$ of the debris-covered glaciers where the debris-covered proportion is less than $20 \%$ and that mass loss is inhibited with increasing debris-covered proportion relative to the no-debris-assumption case (Fig. 5). Although glaciers with debris-covered proportions $>20 \%$ experience inhibited mass loss compared to that of the no-debris assumption, debris-covered glaciers show an

intensive negative mass balance trend on Mount Gongga, and their averaged mass balance is not statistically different from that of debris-free glaciers. This phenomenon was also found on Himalaya glaciers (Kääb et al., 2012), where regionally averaged thinning rates on debris-covered ice are similar to those of debris-free ice despite the widely assumed insulating effect of debris cover. Overall, although the presence of supraglacial debris has a significant insulating effect on the trend of greater negative mass balance on the debris-covered glaciers, especially on the glaciers with debriscovered proportions $>20 \%$, compared to that of the no-debris assumption, $25 \%$ of the debris-covered glaciers on Mount Gongga have experienced accelerated mass loss, and regionally averaged mass loss of debris-covered glaciers is similar to that of

\subsubsection{Debris-cover effect on glacier terminus changes}

Between 1966 and 2009, both retreating and stable glacier termini existed with rates between -45.0 and $0 \mathrm{myr}^{-1}$ (Fig. 6), and $90 \%$ of the glaciers were retreating. As

TCD

7, 2413-2453, 2013

Spatial debris-cover effect on the maritime glaciers

Y. Zhang et al.

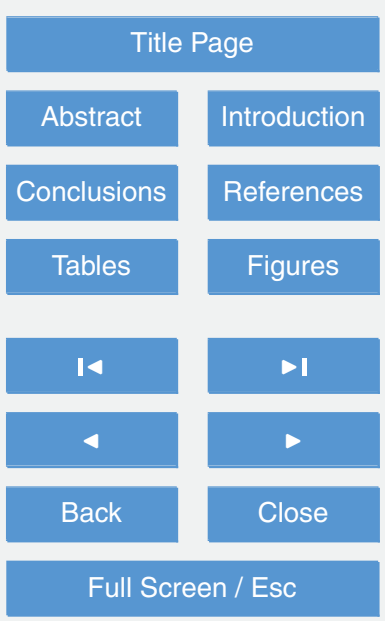

Printer-friendly Version

Interactive Discussion 
illustrated in Fig. 6, no uniform change occurred in the termini of debris-free glaciers with rates between -25.0 and $0 \mathrm{~m} \mathrm{yr}^{-1}$, and $29 \%$ of the debris-free glaciers retreated significantly at retreat rates $>10.0 \mathrm{~m} \mathrm{yr}^{-1}$, the mean retreat rate of Mount Gongga glaciers (hereafter termed "significant retreat"), while $51 \%$ of debris-covered glaciers 5 showed significant retreat with some of the highest retreat rates $\left(\sim-45 \mathrm{myr}^{-1}\right)$ on Mount Gongga. We observed that debris-free glaciers with mean slopes $>30^{\circ}$ exhibited larger retreat rates, and those with mean slopes $<20^{\circ}$ had smaller retreat rates (Fig. 6). In contrast, debris-covered glaciers with gentle slopes exhibited larger retreat rates when the debris-covered proportion is relatively large, and those with steep 10 slopes had relatively smaller retreat rates when the debris-covered proportion is relatively small (Fig. 6). We observed a significant difference of retreat rates between debris-free and debris-covered glaciers, i.e. the mean retreat rate of debris-covered glaciers, $-14.0 \mathrm{~m} \mathrm{yr}^{-1}$, is greater than that of debris-free glaciers, $-8.0 \mathrm{~m} \mathrm{yr}^{-1}$.

\section{Discussion}

\section{$15 \quad 5.1$ Uncertainties in thermal resistances}

The main sources of uncertainty in calculating the thermal resistance of the debris layer using ASTER images come from neglecting the turbulent heat fluxes in the surface energy-balance calculation, the shading effect by surrounding mountains and the presence of water. The approach used in this study is based on the fact that the net radiation is usually the dominant heat source on debris-covered glaciers and the contribution of the turbulent heat fluxes to the total energy balance is normally small (e.g. Mattson and Gardner, 1991; Kayastha et al., 2000; Takeuchi et al., 2000; Nicholson and Benn, 2006; Suzuki et al., 2007), which can be neglected. Zhang et al. (2011; Fig. 8) found the same characteristic of the energy balance at the debris-covered surface on HLG Glacier of this region, especially at the debris layer of $>0.1 \mathrm{~m}$. Suzuki et al. (2007) evaluated the uncertainty in the approach described above caused by neglecting the

TCD

7, 2413-2453, 2013

Spatial debris-cover effect on the maritime glaciers

Y. Zhang et al.

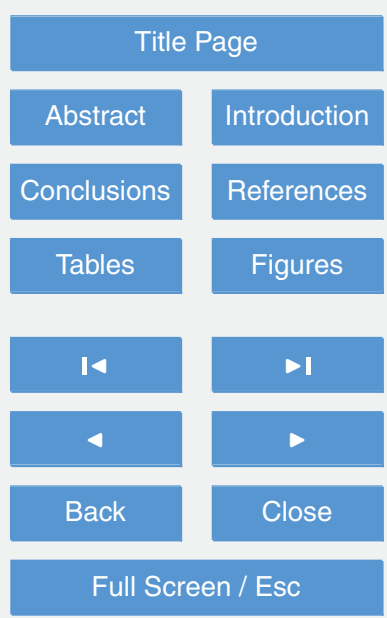

Printer-friendly Version

Interactive Discussion 
turbulent heat fluxes in the surface energy-balance calculation using observed meteorological data, and suggested that this uncertainty is unlikely to affect the spatial pattern of the thermal resistance of the debris layer. Although the shading of solar insolation by surrounding mountains may not affect the thermal resistance of the debris layer 5 (Suzuki et al., 2007), the presence of water in the debris does (Suzuki et al., 2007; Zhang et al., 2012). Hence, knowledge of the meteorological conditions at, before and after the image acquisition date is of vital importance for calculating thermal resistance from ASTER data. In this study, image acquisition was near the middle of the dry winter season of this region, where $75-90 \%$ of the annual precipitation falls in the months 10 of May-October and the mean annual air temperature is high (Su et al., 1992; Li and Su, 1996; Zhang et al., 2010). An analysis of the meteorological conditions observed at AWS and at the precipitation gauge (Fig. 1) shows that the image acquisition days were characterized by high temperatures, cloud-free skies, and a prolonged lack of precipitation. The debris surface was therefore considered to be dry in the calculation of thermal resistance. As discussed above, we believe that the ASTER-derived thermal resistance presents a reasonable view of the spatial distribution of debris thickness on Mount Gongga glaciers, which possibly provides important insight into studying debriscovered glaciers without in situ measurements of the extent, thickness and thermal properties of debris layer at a large scale.

\subsection{Mass balance modeling}

The mass balance reconstruction for the Mount Gongga glaciers was based on the ability to simulate mass balance and sub-debris ice melt rate at a large scale using a surface energy-mass balance model that accounts for the debris-cover effect. The model was validated at the catchment scale by comparing the simulations to observed runoff and glacier ablation for different periods in the HLG catchment (Zhang et al., 2012), one of the glacierized catchments of Mount Gongga (Fig. 1), which contains three debris-covered and four debris-free glaciers. In the calculation, an assumption was made of model parameters that are constant in both space and time (Table 2).

Spatial debris-cover effect on the maritime glaciers

Y. Zhang et al.

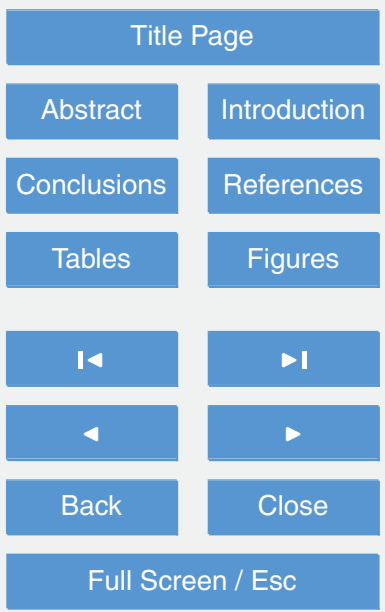

Printer-friendly Version

Interactive Discussion

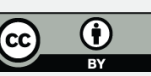


Also, thermal resistances of debris layers in the ablation zones of the Mount Gongga glaciers were considered as constant, although the thermal resistance at a specific pixel may be affected by the ice movement and deposition of supraglacial debris due to the high ice velocity of Mount Gongga glaciers (Song, 1994; Li and Su, 1996; Zhang 5 et al., 2010). Comparison of ASTER-derived thermal resistances in 2008 with those in 2009 at the same pixels on Mount Gongga glaciers indicates that little difference exists in thermal resistances derived from the independent data (Fig. 7). The overall correlation coefficient between thermal resistances in 2008 and those in 2009 is 0.72 (significance level $p<0.001$ ). This finding is in agreement with previous studies (Rana 10 et al., 1997; Nakawo and Rana, 1999; Suzuki et al., 2007), which suggested that the thermal resistance of the debris layer can usually be regarded as constant on debriscovered glaciers. Despite this uncertainty, the model results for the HLG catchment confirmed that the model reconstructed well the long-term mass balance (1952-2009) (Zhang et al., 2012). In particular, the model was able to reliably estimate the ice melt rates beneath various debris thicknesses during different periods (Fig. 8a). The overall aim of this study was not to simulate as accurately as possible the mass balance or spatial variations for any given year but rather to systematically evaluate the impacts of the spatial distribution of debris cover on the average status of Mount Gongga glaciers. A comparison of mean annual mass balances over the period 1998-2007 and mean annual terminus retreat rates over the period 1966-2009 indicates that the mass balance calculated by the surface energy-mass balance model captured the trend of rapid retreat of the glaciers (Fig. 8b). As noted above, we believe that the model presents a reasonable view of the general condition of the mass balance of Mount Gongga glaciers, which possibly provide a useful context for discussing the potential impacts of debris cover and its spatial distribution on the average status of debris-covered glaciers at a large scale.

Spatial debris-cover effect on the maritime glaciers

Y. Zhang et al.

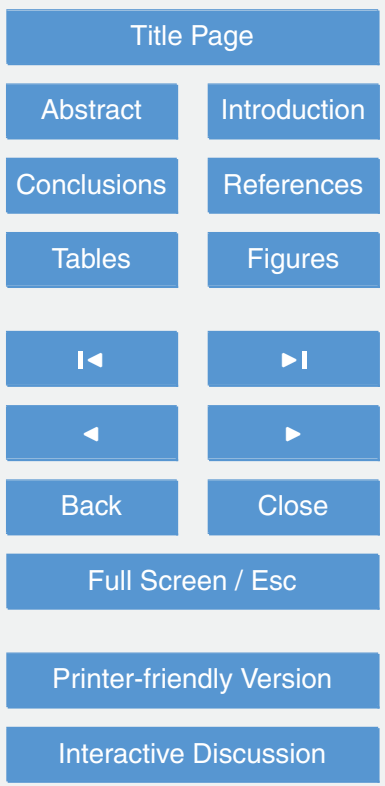




\subsection{Regional differences in the debris-cover effect}

As earlier investigations showed (Su et al., 1985; Zhang et al., 2006, 2007; Lambrecht et al., 2011; Mayer et al., 2011; Scherler et al., 2011; Anderson and Mackintosh, 2012), the significant effect of debris cover in other regions is to reduce mass loss from the 5 glacier, although differences in the proportion of debris cover are apparent from region to region (Table 3). In situ measurements of debris thickness indicate that debris thickness on debris-covered glaciers of other regions (Table 3 ) is generally thicker than that on Mount Gongga glaciers. Although previous investigations have addressed the impact of debris cover on glacier status and runoff at a large scale, they only accounted

10 for the effect of thick debris cover using a multiplicative reduction factor (e.g. Anderson and Mackintosh, 2012; Immerzeel et al., 2012) or regional debris thickness extrapolated from the thickness measurements on a few glaciers with an assumption of similar thickness/elevation distributions on the neighbouring glaciers (e.g. Lambrecht et al., 2011; Mayer et al., 2011) (Table 3). In contrast, our investigation comprehensively considered debris thickness and its spatial characteristics revealed by the ASTER-derived thermal resistance of the debris layer on the glaciers, with the consequence that we found apparently spatial differences in the debris-cover effect on the average status of the Mount Gongga maritime glaciers. In particular, the presence of debris and its inhomogeneous distribution accelerate the melting on $\sim 10.2 \%$ of the total ablation zone and produce a more negative mass balance on $\sim 25 \%$ of the debris-covered glaciers. Furthermore, a widely distributed surface on the Mount Gongga glaciers, composed of co-existing debris-covered ice, bare ice, ice cliffs and supraglacial ponds in the ablation zone, makes disproportionately large contributions to ablation (Sakai et al., 2000, 2002). Consequently, regionally averaged mass loss of debris-covered glaciers is similar to that of debris-free glaciers on Mount Gongga, which is contrary to expectations.

In addition, we observed that the mean terminus retreat rate of debris-covered glaciers $\left(-14.0 \mathrm{myr}^{-1}\right)$ is greater than that of debris-free glaciers $\left(-8.0 \mathrm{myr}^{-1}\right)$. This finding is different from many eastern and central Himalayan debris-covered glaciers

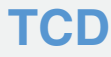

$7,2413-2453,2013$

Spatial debris-cover effect on the maritime glaciers

Y. Zhang et al.

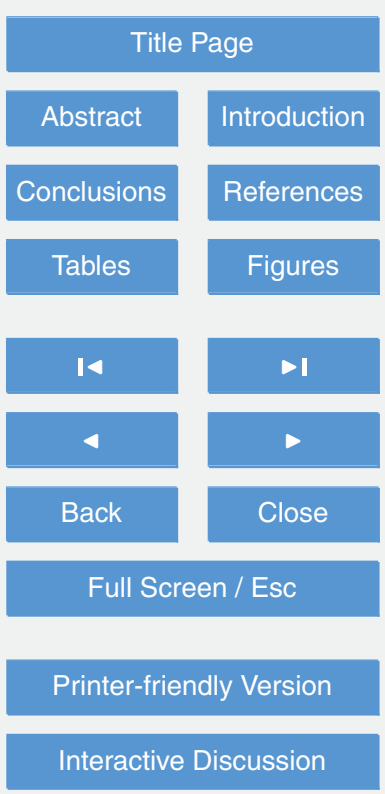

Interactive Discussion 
with stagnant low-gradient terminus regions (Scherler et al., 2011). According to in situ observations of ice velocities on HLG, DGB and XGB glaciers during different periods (Song, 1994; Li and Su, 1996; Zhang et al., 2011), the ice velocities of these glaciers are largely higher than those of glaciers in other regions of the Tibetan Plateau ( $\mathrm{Li}$ 5 and Su, 1996; Shi and Liu, 2000). Ice velocities in the ablation zone of HLG Glacier generally vary from 28.8 to $205.0 \mathrm{myr}^{-1}$ (Zhang et al., 2010). In contrast, most Himalaya glaciers have low ice velocities and shallow termini (Scherler et al., 2011; Benn et al., 2012). Note that mean surface slopes in the terminus region of $<8^{\circ}$ promote the development of stagnant ice (Scherler et al., 2011). Mean surface slopes in the ter10 minus regions of most debris-covered glaciers on Mount Gongga are greater than $8^{\circ}$, which facilitate frequent rock falls and snow avalanches ( $\mathrm{Li}$ and $\mathrm{Su}, 1996)$. It must be pointed out that the widespread presence of supraglacial debris and ponds on these glaciers can accelerate glacier terminus disintegration by exposing ice faces at the surface (Röhl, 2008), lowering the glacier surface (Sakai and Fujita, 2010) and backwasting, a related topographic inversion processes, can yield complex debris assemblages and numerous supraglacial ponds (Benn and Evans, 2010; Benn et al., 2012). Consequently, high ice velocities, relatively steep surface slopes and the intensely inhomogeneous ice melting caused by widespread debris cover lead to the unstable fronts of the debris-covered glaciers on Mount Gongga, which accelerates their terminus disintegration and retreat.

\section{Conclusions}

Mount Gongga offers an opportunity to study a monsoonal maritime glacier system with debris-covered and debris-free glaciers in the south-eastern Tibetan Plateau, where specific, though incomplete, information is available for both the glaciology and meteorology. Sixty-eight percent of Mount Gongga glaciers have extensive mantles of supraglacial debris in the ablation zones, where the debris-covered proportions of the total glacier area vary from $1.74 \%$ to $53.0 \%$. These glaciers show a general

Spatial debris-cover effect on the maritime glaciers

Y. Zhang et al.

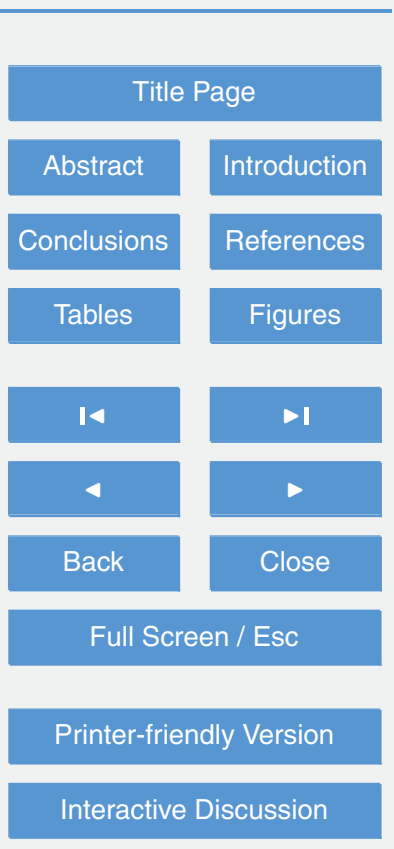


downglacier increasing trend in debris thickness with significant spatial inhomogeneity at each site. High-resolution in situ measurements of debris thickness indicate that thin debris thicknesses of $<0.03 \mathrm{~m}$ are widely distributed on the glaciers. Against the background of global warming, although the presence of supraglacial debris has a sig5 nificant insulating effect on the trend of greater negative mass balance on the debriscovered glaciers, especially on the glaciers with debris-covered proportions $>20 \%$, it accelerates the trend of faster ice melting on $\sim 10.2 \%$ of the total ablation area and produces a more negative mass balance, which is primarily caused by temperature rise, on $\sim 25 \%$ of the debris-covered glaciers on Mount Gongga. The consequence is 10 that regionally averaged mass balance of debris-covered glaciers is not statistically different from that of debris-free glaciers with all glaciers exhibiting an intensive negative mass balance trend on Mount Gongga. Also, the intensely inhomogeneous ice melting caused by widespread debris cover in association with high ice velocities and relatively steep surface leads to active terminus regions of the debris-covered glaciers, of which the terminus retreat rates are faster than those of the debris-free glaciers.

Debris-covered glaciers are common in the Tibetan Plateau and surroundings, as well as in many other mountain ranges around the world (Nicholson and Benn, 2006; Zhang et al., 2007, 2012; Anderson and Mackintosh, 2012; Brenning et al., 2012). Although the percentages of debris cover of the studied debris-covered glaciers vary from $2 \%$ to $36 \%$ (Table 3 ), the impact of the debris cover on both the ice-melting rates and spatial patterns of mass loss is considerably significant in each region and shows apparent systematic differences from region to region, with the consequence that the inclusion of debris cover in estimates of glacier mass balance and runoff at a large scale is of vital importance. Despite numerous simplifications, our physicallybased techniques for mapping the distribution of supraglacial debris thickness using satellite imagery and estimating the debris-cover effects using a surface energy-mass balance approach can systematically assess the significance of debris cover and its influence on spatial patterns of ice melting and mass balance at a regional scale. These approaches possibly provide important insight into studying the average status
TCD

$7,2413-2453,2013$

Spatial debris-cover effect on the maritime glaciers

Y. Zhang et al.

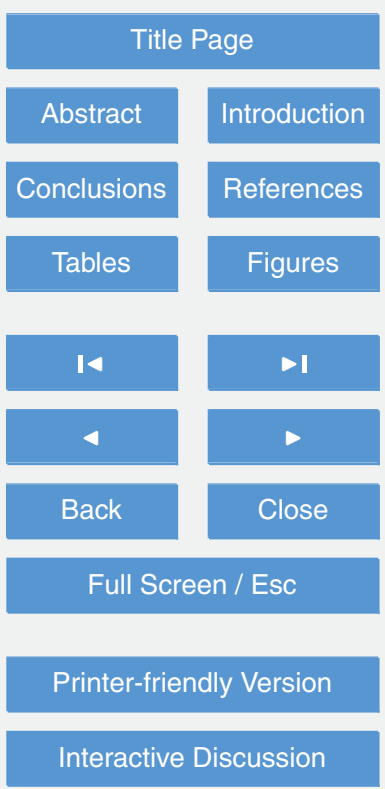


of debris-covered glaciers and its impacts at the regional scale, including long-term variation of mass balance and water resources and increased frequency of glacier lake outburst floods.

Acknowledgements. We thank the Gongga Alpine Ecosystem Observation and Research Sta5 tion (GAEORS) of the Chinese Ecological Research Network and the AIST GEO for providing the meteorological data and ASTER data, respectively. We thank B. Pan of Lanzhou University for providing 2009 glacier outline data for Mount Gongga. This work was supported by the National Science and Technology Support Program of China (2012BAC19B07), the NSFC (40701032), and the Funding Program for next generation world-leading researchers, Japan

10 Society for the Promotion of Science, and CREST project of Japan Science and Technology Agency.

\section{References}

Anderson, B. and Mackintosh, A.: Controls on mass balance sensitivity of maritime glaciers in the Southern Alps, New Zealand: the role of debris cover, J. Geophys. Res., 117, F01003, doi:10.1029/2011JF002064, 2012.

Benn, D. I. and Evans, D. J.: Glaciers and Glaciation, Hodder Education, London, 2010.

Benn, D. I., Bolch, T., Hands, K., Gulley, J., Luckman, A., Nicholson, L. I., Quincey, D., Thompson, S., Toumi, R., and Wiseman, S.: Response of debris-covered glaciers in the Mount Everest region to recent warming, and implications for outburst flood hazards, Earth-Sci. Rev., 114, 156-174, doi:10.1016/j.earscirev.2012.03.008, 2012.

Brenning, A., Peña, M. A., Long, S., and Soliman, A.: Thermal remote sensing of ice-debris landforms using ASTER: an example from the Chilean Andes, The Cryosphere, 6, 367-382, doi:10.5194/tc-6-367-2012, 2012.

Cao, Z. and Cheng, G.: Preliminary analyses of hydrological characteritics of Hailuogou Glacier on the eastern slope of the Gongga Mountain, in: Glaciers and Environment in the QinhaiXizang (Tibet) Plateau (I) - the Gongga Mountain, edited by: Xie, Z. and Kotlyakov, V. M., Science Press, Beijing and New York, 143-156, 1994.

Casey, K. A., Kääb, A., and Benn, D. I.: Geochemical characterization of supraglacial debris via in situ and optical remote sensing methods: a case study in Khumbu Himalaya, Nepal, The Cryosphere, 6, 85-100, doi:10.5194/tc-6-85-2012, 2012.
Spatial debris-cover effect on the maritime glaciers

Y. Zhang et al.

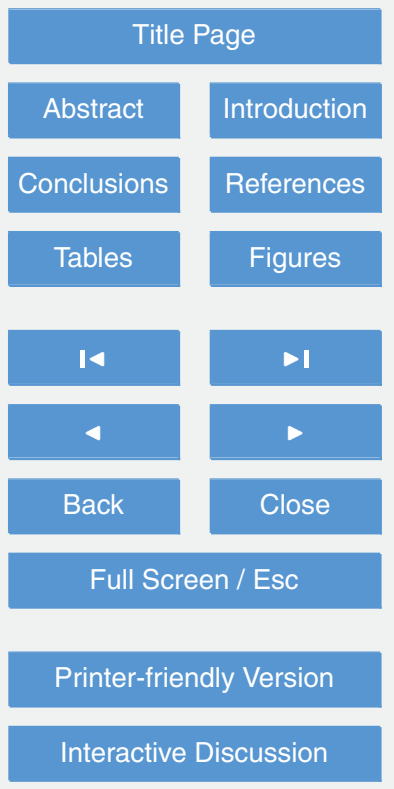

Interactive Discussion 
Dyurgerov, M. B. and Meier, M. F.: Glaciers and the Changing Earth System: A 2004 Snapshot, Institute of Arctic and Alpine Research, Occasional Paper 58, University of Colorado at Boulder, Boulder, Colorado, USA, 2005.

ERSDAC: http://gds.aster.ersdac.jspacesystems.or.jp/gds_www2002/exhibition_e/a_products_ e/set_a_produ_e.html, (last access: May 2009), 2002.

Fan, Y. and van den Dool, H. V. D.: A global monthly land surface air temperature analysis for 1948-present, J. Geophys. Res., 113, D01103, doi:10.1029/2007JD008470, 2008.

Fujisada, H., Bailey, G. B., Kelly, G. G., Hara, S., and Abrams, M. J.: ASTER DEM performance, IEEE T. Geosci. Remote, 43, 2702-2714, 2005.

10 Fujita, K.: Effect of dust event timing on glacier runoff: sensitivity analysis for a Tibetan glacier, Hydrol. Process., 21, 2892-2896, doi:10.1002/hyp.6504, 2007.

Fujita, K.: Effect of precipitation seasonality on climatic sensitivity of glacier mass balance, Earth Planet. Sc. Lett., 276, 14-19, doi:10.1016/j.epsl.2008.08.028, 2008.

Fujita, K. and Ageta, Y.: Effect of summer accumulation on glacier mass balance on the Tibetan Plateau revealed by mass-balance model, J. Glaciol., 46, 244-252, 2000.

Fujita, K. and Nuimura, T.: Spatially heterogeneous wastage of Himalayan glaciers, P. Natl. Acad. Sci. USA, 108, 14011-14014, doi:10.1073/pnas.1106242108 DCSupplemental, 2011.

Hirabayashi, Y., Kanae, S., Emori, S., Oki, T., and Kimoto, M.: Global projections of changing risks of floods and droughts in a changing climate, Hydrolog. Sci. J., 53, 754-772, 2008.

20

Immerzeel, W., van Beek, L. P. H., and Bierkens, M. F. P.: Climate change will affect the Asian water towers, Science, 328, 1382-1385, doi:10.1126/science.1183188, 2010.

Immerzeel, W., van Beek, L. P. H., Konz, M., Shrestha, A. B., and Bierkens, M. F. P.: Hydrological response to climate change in a glacierized catchment in the Himalayas, Climatic Change, 110, 721-736, doi:10.1007/s10584-011-0143-4, 2012.

Kääb, A., Berthier, E., Nuth, C., Gardelle, J., and Arnaud, Y.: Contrasting patterns of early twenty-first-century glacier mass change in the Himalayas, Nature, 488, 495-498, doi:10.1038/nature11324, 2012.

Kalnay, E., Kanamitsu, M., Kistler, R., Collins, W., Deaven, D., Gandin, L., Iredell, M., Saha, S., White, G., Woollen, J., Zhu, Y., Chelliah, M., Ebisuzaki, W., Higgins, W., Janowiak, J., $30 \quad$ Mo, K. C., Ropelewski, C., Wang, J., Leetmaa, A., Reynolds, R., Jenne, R., and Joseph, D.: The NCEP/NCAR 40-year reanalysis project, B. Am. Meteorol. Soc., 77, 437-471, 1996.
TCD

7, 2413-2453, 2013

Spatial debris-cover

effect on the maritime glaciers

Y. Zhang et al.

Title Page

Abstract

Introduction

Conclusions

References

Tables

Figures

14

DI

4

Back

$>$

Close

Full Screen / Esc

Printer-friendly Version

Interactive Discussion 
Kaser, G., Groÿhauser, M., and Marzeion, B.: Contribution potential of glaciers to water availability in different climate regimes, P. Natl. Acad. Sci. USA, 107, 20223-20227, doi:10.1073/pnas.1008162107, 2010.

Kayastha, R. B., Takeuchi, Y., Nakawo, M., and Ageta, Y.: Practical prediction of ice melting be-

5 neath various thickness of debris cover on Khumbu Glacier, Nepal, using a positive degreeday factor, IAHS-AISH P., 264, 71-81, 2000.

Kraus, H.: An energy balance model for ablation in mountainous areas, IAHS-AISH P., 104, 74-82, 1975.

Lambrecht, A., Mayer, C., Hagg, W., Popovnin, V., Rezepkin, A., Lomidze, N., and Svanadze, D.: A comparison of glacier melt on debris-covered glaciers in the northern and southern Caucasus, The Cryosphere, 5, 525-538, doi:10.5194/tc-5-525-2011, 2011.

Li, J. and Su, Z.: Glaciers in the Hengduan Mountains, Science Press, Beijing, 1-110, 1996 (in Chinese).

Liu, Q., Liu, S., Zhang, Y., Wang, X., Zhang, Y., Guo, W., and Xu, J.: Recent shrinkage and hydrological response of Hailuogou glacier, a monsoon temperate glacier on the east slope of Mount Gongga, China, J. Glaciol., 56, 215-224, doi:10.3189/002214310791968520, 2010.

Liu, S., Zhang, Y., Zhang, Y., and Ding, Y.: Estimation of glacier runoff and future trends in the Yangtze River source region, China, J. Glaciol., 55, 353-362, doi:10.3189/002214309788608778, 2009.

20 Mattson, L. E. and Gardner, J. S.: Energy exchanges and ablation rates on the debris-covered Rakhiot Glacier, Pakistan, Z. Gletscherk. Glazialgeol., 25, 17-32, 1991.

Mattson, L. E., Gardner, J. S., and Young, G. J.: Ablation on debris covered glaciers: an example from the Rakhiot Glacier, Punjab, Himalaya, IAHS-AISH P., 218, 289-296, 1993.

Mayer, C., Lambrecht, A., Hagg, W., and Narozhny, Y.: Glacial debris cover and melt water production for glaciers in the Altay, Russia, The Cryosphere Discuss., 5, 401-430, doi:10.5194/tcd-5-401-2011, 2011.

Mihalcea, C., Brock, B. W., Diolaiuti, G., D’Agata, C., Citterio, M., Kirkbride, M. P., Cutler, M. E. J., and Smiraglia, C.: Using ASTER satellite and ground-based surface temperature measurements to derive supraglacial debris cover and thickness patterns on Miage Glacier,

$30 \quad$ Cold Reg. Sci. Technol., 52, 341-354, doi:10.1016/j.coldregions.2007.03.004, 2008.

Mitchell, T. D. and Jones, P. D.: An improved method of constructing a database of monthly climate observations and associated high-resolution grids, Int. J. Climatol., 25, 693-712, doi:10.1002/joc.1181, 2005.

Spatial debris-cover

effect on the maritime glaciers

Y. Zhang et al.

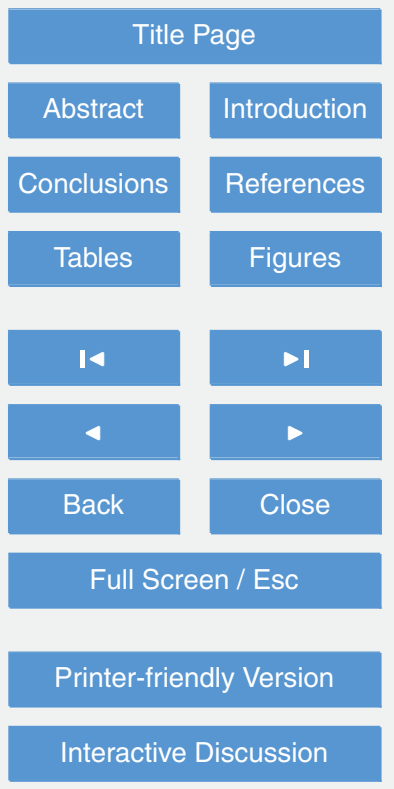

Interactive Discussion

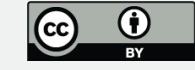


Nakawo, M. and Rana, B.: Estimate of ablation rate of glacier ice under a supraglacial debris layer, Geogr. Ann. A, 81, 695-701, 1999.

Nakawo, M. and Young, G. J.: Field experiments to determine the effect of a debris layer on ablation of glacier ice, Ann. Glaciol., 2, 85-91, 1981.

5 Nakawo, M. and Young, G. J.: Estimate of glacier ablation under a debris layer from surface temperature and meteorological variables, J. Glaciol., 28, 29-34, 1982.

Nicholson, L. and Benn, D. I.: Calculating ice melt beneath a debris layer using meteorological data, J. Glaciol., 52, 463-470, doi:10.3189/172756506781828584, 2006.

Oerlemans, J. and Fortuin, J. P. F.: Sensitivity of glaciers and small ice caps to greenhouse warming, Science, 258, 115-117, doi:10.1126/science.1258.5079.115, 1992.

Østrem, G.: Ice melting under a thin layer of moraine and the existence of ice cores in moraine ridges, Geogr. Ann., 41, 228-230, 1959.

Pan, B. T., Zhang, G. L., Wang, J., Cao, B., Geng, H. P., Wang, J., Zhang, C., and Ji, Y. P.: Glacier changes from 1966-2009 in the Gongga Mountains, on the south-eastern margin of the Qinghai-Tibetan Plateau and their climatic forcing, The Cryosphere, 6, 1087-1101, doi:10.5194/tc-6-1087-2012, 2012.

Paterson, W. S. B.: The Physics of Glaciers, Elsevier Science Ltd, Oxford, 1994.

Paul, F., Huggel, C., and Kääb, A.: Combining satellite multispectral image data and a digital elevation model for mapping debris-covered glaciers, Remote Sens. Environ., 89, 510-518, doi:10.1016/j.rse.2003.11.007, 2004.

Pu, J.: Glacier Inventory of China VIII (the Changjiang (Yangtze) River Drainage Basin), Gansu Culture Publishing House, Lanzhou, 117-129, 1994 (in Chinese).

Racoviteanu, A. E., Paul, F., Paup, B., Khalsa, S. H. S., and Armstrong, R.: Challeges and recommendatios in mapping of glacier parameters from space: results of the 2008 Global Land Ice Measurements from Space (GLIMS) workshop, Boulder, Colorado, USA, Ann. Glaciol., 50, 53-69, doi:10.3189/172756410790595804, 2009.

Rana, B., Nakawo, M., Fukushima, Y., and Ageta, Y.: Application of a conceptual precipitationrunoff model (HYCY-MODEL) in a debris-covered glacierized basin in the Langtang Valley, Nepal Himalaya, Ann. Glaciol., 25, 226-231, 1997.

30 Reid, T. D. and Brock, B. W.: An energy-balance model for debris-covered glaciers including heat conduction through the debris layer, J. Glaciol., 56, 903-916, doi:10.3189/002214310794457218, 2010.

Spatial debris-cover

effect on the maritime glaciers

Y. Zhang et al.

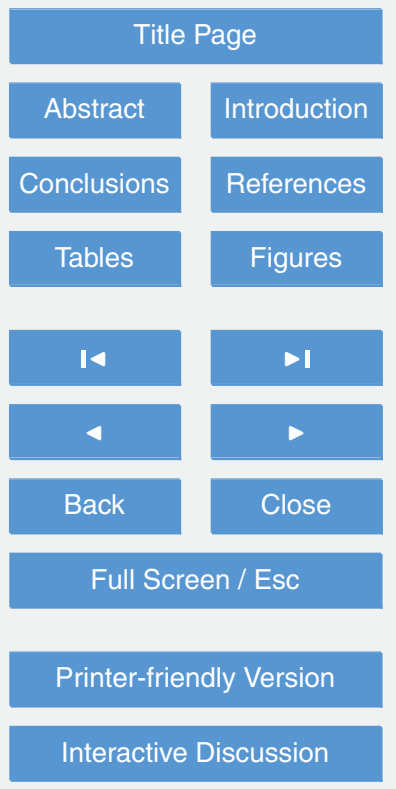


Röhl, K.: Characteristics and evolution of supraglacial ponds on debris-covered Tasman Glacier, New Zealand, J. Glaciol., 54, 867-880, doi:10.3189/002214308787779861, 2008.

Sakai, A. and Fujita, K.: Formation conditions of supraglacial lakes on debris-covered glaciers in the Himalayas, J. Glaciol., 56, 177-181, doi:10.3189/002214310791190785, 2010.

5 Sakai, A., Takeuchi, N., Fujita, K., and Nakawo, M.: Role of supraglacial ponds in the ablation processes of a debris-covered glacier in the Nepal Himalayas, IAHS-AISH P., 264, 119-130, 2000.

Sakai, A., Nakawo, M., and Fujita, K.: Distribution characteristics and energy balance of Ice cliffs on debris-covered glaciers, Nepal Himalaya, Arct. Antarct. Alp. Res., 34, 12-19, 2002.

Scherler, D., Bookhagen, B., and Strecker, M. R.: Spatially variable response of Himalayan glaciers to climate change affected by debris cover, Nat. Geosci., 4, 156-159, doi:10.1038/ngeo1068, 2011.

Sekiguchi, S., Tanaka, Y., Kojima, I., Yamamoto, N., Yokoyama, S., Tanimura, Y., Nakamura, R., Iwao, K., and Tsuchida, S.: Design principles and it overviews of the GEO grid, IEEE Syst. J.,

$15 \quad$ 2, 374-389, doi:10.1109/JSYST.2008.925976, 2008.

Shi, Y. and Liu, S.: Estimation on the response of glaciers in China to the global warming in the 21st century, Chinese Sci. Bull., 45, 668-672, 2000.

Song, G.: Movement features of Hailuogou Glacier in the Gongga Mountain, in: Glaciers and Environment in the Qinhai-Xizang (Tibet) Plateau (I) - The Gongga Mountain, edited by: Xie, Z. and Kotlyakov, V. M., Science Press, Beijing and New York, 110-120, 1994.

Su, Z., Song, G., Wang, L., Zhang, W., Zhang, H., Yang, C., and Liang, D.: Modern glaciers in Mt Tuomer Distric, in: Glacial and Weather in Mt Tuomuer District, Tianshan, edited by: Mountaineering and Expedition Team of Chinese Academy of Sciences, Xinjiang Renmin Press, Urumuqi, 69-75, 1985 (in Chinese).

Su, Z., Liu, S., Wang, N., and Shi, A.: Recent fluctuations of glaciers in the Gongga Mountains, Ann. Glaciol., 16, 163-167, 1992.

Suzuki, R., Fujita, K., and Ageta, Y.: Spatial distribution of the thermal properties on debriscovered glaciers in the Himalayas derived from ASTER data, Bull. Glaciol. Res., 24, 13-22, 2007.

30 Takeuchi, Y., Kayastha, R. B., and Nakawo, M.: Characteristics of ablation and heat balance in debris-free and debris-covered areaas on Khumbu Glacier, Nepal Himalayas, in the premonsoon season, IAHS-AISH P., 264, 53-61, 2000.
TCD

7, 2413-2453, 2013

Spatial debris-cover

effect on the maritime glaciers

Y. Zhang et al.

Title Page

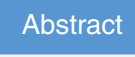

Introduction

Conclusions

Tables

References

\section{Figures}

14

I

4

Back

$>$

Close

Full Screen / Esc

Printer-friendly Version

Interactive Discussion 
Yao, T., Thompson, L., Yang, W., Yu, W., Gao, Y., Guo, X., Yang, X., Duan, K., Zhao, H., Xu, B., $\mathrm{Pu}$, J., Lu, A., Xiang, Y., Kattel, D. B., and Joswiak, D.: Different glacier status with atmospheric circulations in Tibetan Plateau and surroundings, Nature Clim. Change, 2, 663-667, doi:10.1038/nclimate1580, 2012.

5 Yatagai, A., Arakawa, O., Kamiguchi, K., Kawamoto, H., Nodzu, M. I., and Hamada, A.: A 44year daily gridded precipitation dataset for Asia based on a dense network of rain gauges, SOLA, 5, 137-140, doi:10.2151/sola.2009-035, 2009.

Zhang, Y., Liu, S., Ding, Y., and Shangguan, D.: Preliminary study of mass balance on the Keqicar Baxi Glacier on the south slopes of Tianshan Mountains, J. Glac. Geocry., 28, 477484, 2006 (in Chinese with English abstract).

Zhang, Y., Liu, S., and Ding, Y.: Glacier meltwater and runoff modelling, Keqicar Baqi glacier, southwestern Tien Shan, China, J. Glaciol., 53, 91-98, doi:10.3189/172756507781833956, 2007.

Zhang, Y., Fujita, K., Liu, S., Liu, Q., and Wang, X.: Multi-decadal ice-velocity and elevation changes of a monsoonal maritime glacier: Hailuogou Glacier, China, J. Glaciol., 56, 65-74, doi:10.3189/002214310791190884, 2010.

Zhang, Y., Fujita, K., Liu, S., Liu, Q., and Nuimura, T.: Distribution of debris thickness and its effect on ice melt at Hailuogou Glacier, southeastern Tibetan Plateau, using in situ surveys and ASTER imagery, J. Glaciol., 57, 1147-1157, doi:10.3189/002214311798843331, 2011.

Zhang, Y., Hirabayashi, Y., and Liu, S.: Catchment-scale reconstruction of glacier mass balance using observations and global climate data: case study of the Hailuogou catchment, southeastern Tibetan Plateau, J. Hydrol., 444-445, 146-160, doi:10.1016/j.jhydrol.2012.04.014, 2012.

\section{Spatial debris-cover effect on the maritime glaciers \\ Y. Zhang et al.}

Title Page

Abstract Introduction

Conclusions

Tables

References

Figures

I

$-1$

4

Back

Close

Full Screen / Esc

Printer-friendly Version

Interactive Discussion 
Table 1. Characteristics of five glaciers with length $>10 \mathrm{~km}$ and their debris-cover effects. Glacier area, length and elevation are derived from the CGI (Pu, 1994). Mean slope is obtained from the DEM. "Debris coverage" denotes the debris-covered proportion of the total glacier area.

\begin{tabular}{lrrrrrrr}
\hline Glacier & Elevation (ma.s.l.) & Area $\left(\mathrm{km}^{2}\right)$ & Length $(\mathrm{km})$ & Slope $\left({ }^{\circ}\right)$ & $\begin{array}{r}\text { Debris coverage } \\
(\%)\end{array}$ & $\begin{array}{r}\text { Debris-cover effect }(\%) \\
\text { Accelerating }\end{array}$ & Insulating \\
\hline HLG & $2990-7556$ & 25.7 & 13.1 & 16.0 & 6.4 & 44.0 & 17.0 \\
DGB & $3660-6684$ & 21.2 & 11.0 & 7.3 & 16.8 & 3.0 & 56.0 \\
MZG & $3600-6886$ & 26.8 & 11.6 & 22.2 & 1.74 & 2.0 & 11.0 \\
YZG & $3680-7556$ & 32.2 & 11.7 & 13.4 & 11.7 & 41.0 & 50.1 \\
NMGG & $3460-6540$ & 16.7 & 10.0 & 10.5 & 20.1 & 17.0 & 35.6 \\
\hline
\end{tabular}

Spatial debris-cover effect on the maritime glaciers

Y. Zhang et al.

Title Page

Abstract

Conclusions

Tables

I

4

Back
Introduction

References

Figures

DI

$>$

Close

Full Screen / Esc

Printer-friendly Version

Interactive Discussion 
Table 2. A summary of the values of parameters used to calculate mass balance.

\begin{tabular}{lccl}
\hline Parameter & Value & Unit & Source \\
\hline Temperature lapse rate & 4.3 & ${ }^{\circ} \mathrm{C} \mathrm{km}^{-1}$ & Cao and Cheng (1994) \\
Precipitation gradient & 18 & $\%\left(100 \mathrm{~m}^{-1}\right.$ & Zhang et al. (2012) \\
Snow/rain temperature threshold & 2.0 & ${ }^{\circ} \mathrm{C}$ & Liu et al. (2009) \\
Albedo of debris-free ice & 0.3 & - & Zhang et al. (2011) \\
Albedo of fresh snow & 0.8 & - & Li and Su (1996) \\
Density of ice & 900 & $\mathrm{~kg} \mathrm{~m}^{-3}$ & Paterson (1994) \\
Density of snow & 415 & $\mathrm{~kg} \mathrm{~m}^{-3}$ & Zhang et al. (2012) \\
\hline
\end{tabular}

Spatial debris-cover effect on the maritime glaciers

Y. Zhang et al.

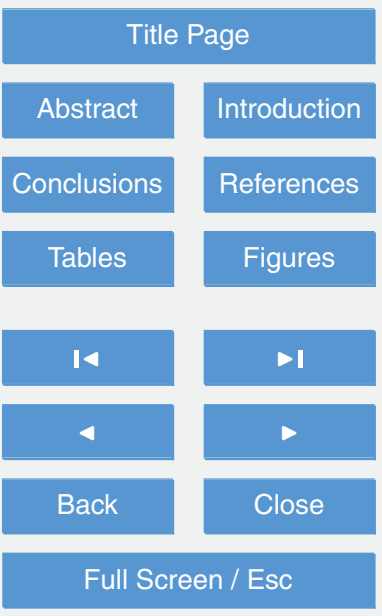

Printer-friendly Version

Interactive Discussion 
Table 3. Regional differences in the debris-cover effect. MRF is multiplicative reduction factor.

\begin{tabular}{|c|c|c|c|c|}
\hline Region & Debris (\%) & Debris-cover effect & Debris thickness & Reference \\
\hline South Alps, New Zealand & 8.0 & Insulating effect & $\begin{array}{l}0-3 \mathrm{~m} \\
\text { Consider thick debris with } \\
\text { a MRF }\end{array}$ & $\begin{array}{l}\text { Anderson and Mackin- } \\
\text { tosh (2012) }\end{array}$ \\
\hline Caucasus & $8.1-23.0$ & Insulating effect & $\begin{array}{l}\text { Extrapolation from } \\
\text { observed thicknesses } \\
\text { on few glaciers }\end{array}$ & Lambrecht et al. (2011) \\
\hline Altay & $3.7-25.8$ & Insulating effect & $\begin{array}{l}\text { Extrapoalation from } \\
\text { observed thickness } \\
\text { on few glaciers }\end{array}$ & Mayer et al. (2011) \\
\hline Tuomur, Tien Shan & $7.5-22.0$ & $\begin{array}{l}\text { Insulating effect, and } \\
\text { accelerating in } 2 \%^{\mathrm{a}} \text { of } \\
\text { ablation area }\end{array}$ & $\begin{array}{l}0-2.5 \mathrm{~m} \\
\text { Some large rocks piled up } \\
\text { to several meters }\end{array}$ & $\begin{array}{l}\text { Su et al. (1985) } \\
\text { Zhang et al. (2006) } \\
\text { Zhang et al. (2007) }\end{array}$ \\
\hline Himalaya and Karakorum & $2.0-36.0$ & Insulating effect & $\begin{array}{l}\text { Consider the extent of de- } \\
\text { bris }\end{array}$ & Scherler et al. (2011) \\
\hline Langtang, Himalaya & 19.0 & Insulating effect & Use a MRF $(0.15 / 0.7)$ & Immerzeel et al. (2012) \\
\hline Mount Gongga & 13.5 & $\begin{array}{l}\text { Accelerating effect in } \\
10.2 \% \text { of ablation area, } \\
\text { and insulating in } 40.8 \%\end{array}$ & $\begin{array}{l}0-1.4 \mathrm{~m} \\
\text { Consider spatial distribu- } \\
\text { tion of debris thickness }\end{array}$ & This work \\
\hline
\end{tabular}

a It is calculated from observed data of Su et al. (1985).

${ }^{b}$ Regional debris thicknesses are extrapolated from observed thicknesses on few glaciers with an assumption of similar thickness/elevation distribution on the neighbouring glaciers.

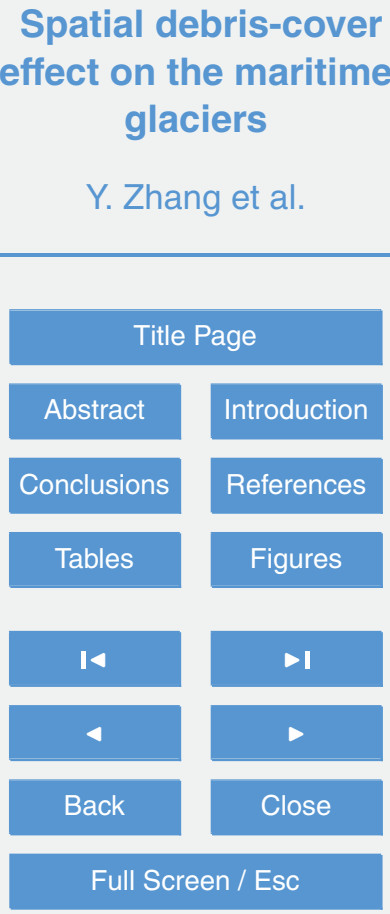

Printer-friendly Version

Interactive Discussion 

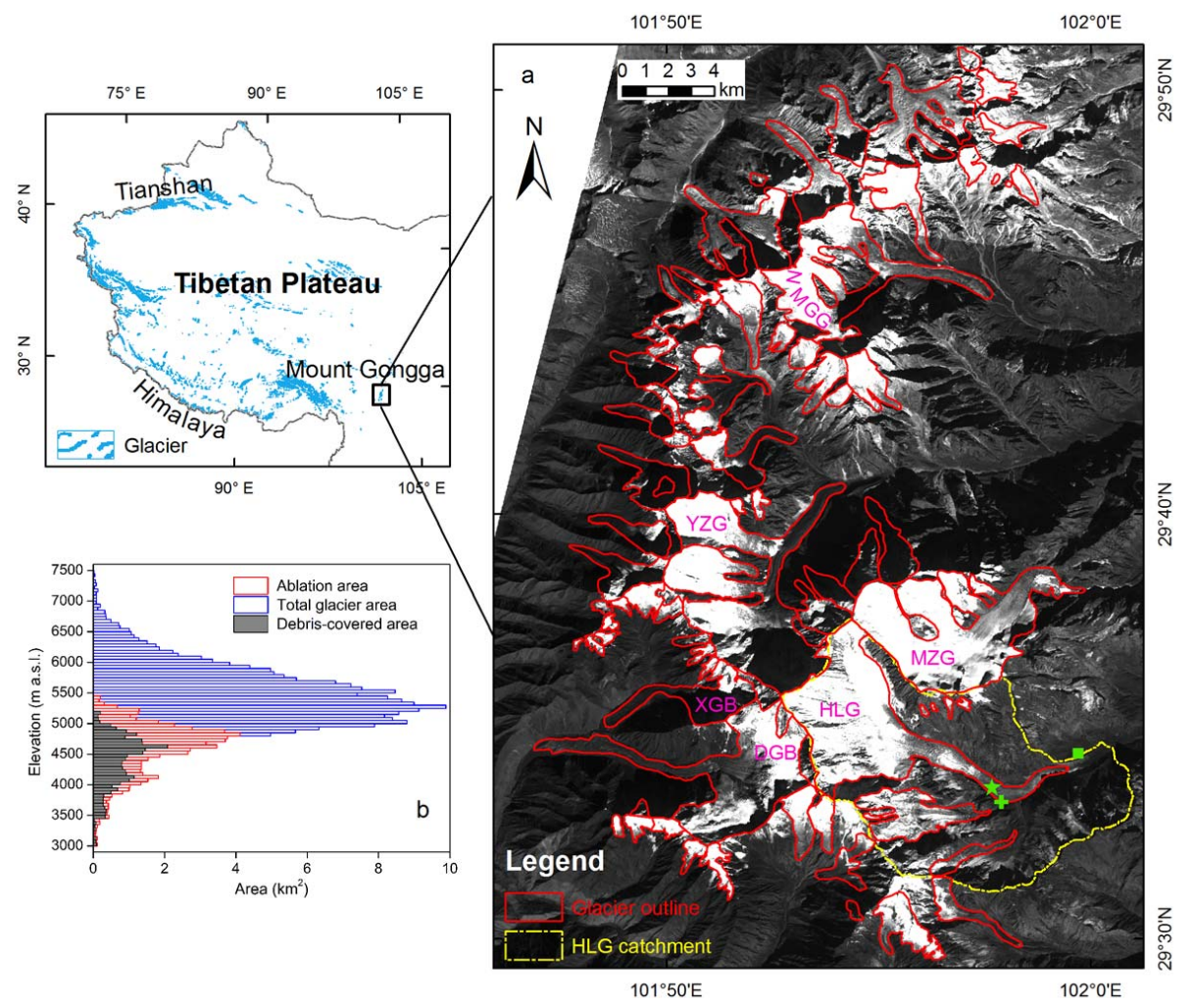

TCD

7, 2413-2453, 2013

Spatial debris-cover effect on the maritime glaciers

Y. Zhang et al.

Title Page

Abstract

Conclusions

Tables

I

4

Back
Introduction

References

Figures

$>1$

$>$

Close

\section{Full Screen / Esc}

Fig. 1. (a) Map of Mount Gongga glaciers in the south-eastern Tibetan Plateau, and (b) areaaltitude distributions of total glacier (blue), ablation area (red) and debris-covered surface (grey). The green square, star, and cross denote GAEORS, AWS and precipitation gauge, respectively. The yellow outline is the Hailuogou (HLG) catchment.

Interactive Discussion 


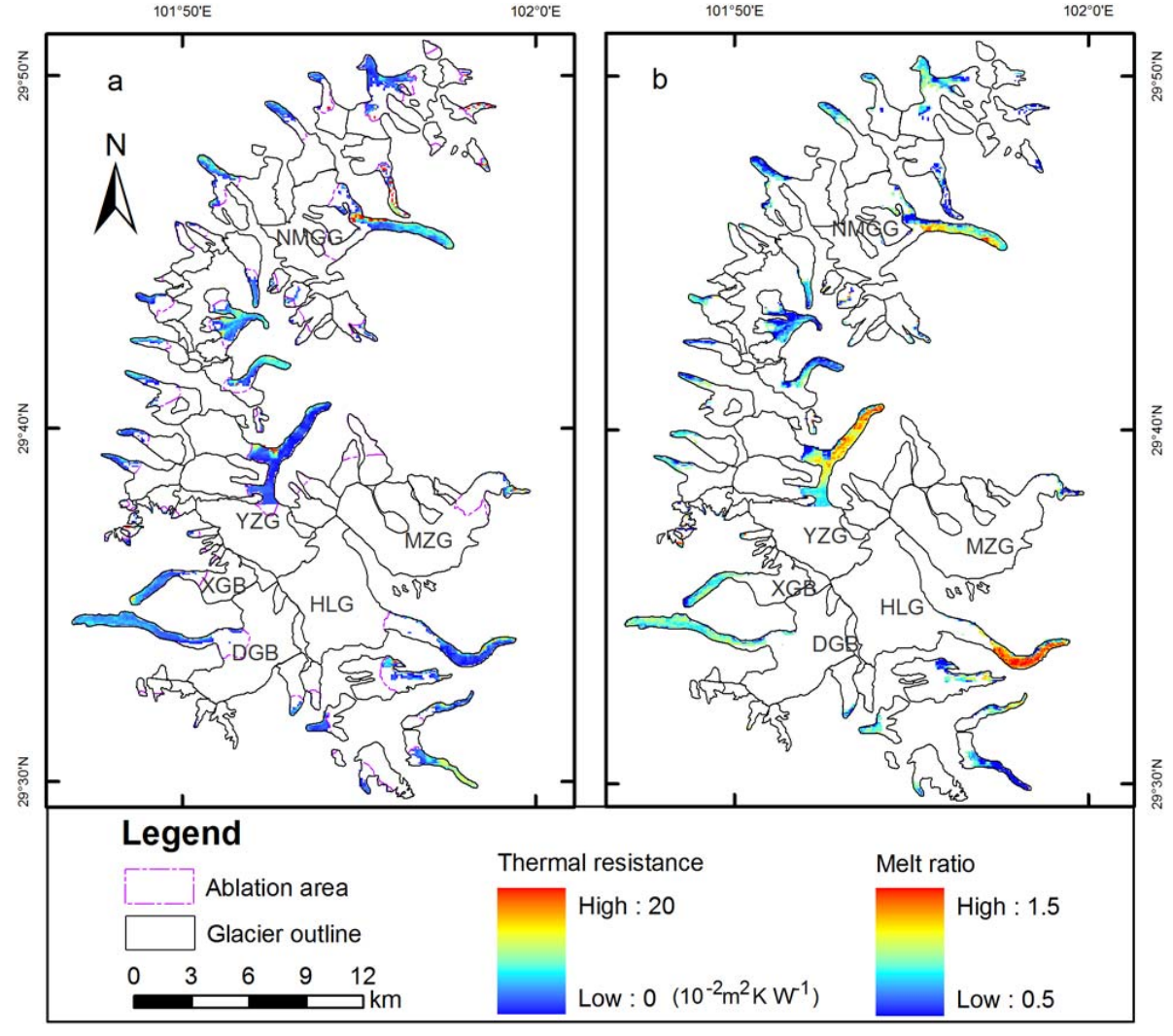

Fig. 2. Spatial distributions of ASTER-derived thermal resistance of the debris layer (a) and the melt ratio (b) in the ablation zones of Mount Gongga glaciers.

\section{TCD}

7, 2413-2453, 2013

Spatial debris-cover effect on the maritime

glaciers

Y. Zhang et al.

Title Page

Abstract

Introduction

Conclusions

References

Tables

Figures

14

$>1$

4

Back

Close

\section{Full Screen / Esc}

Printer-friendly Version

Interactive Discussion 


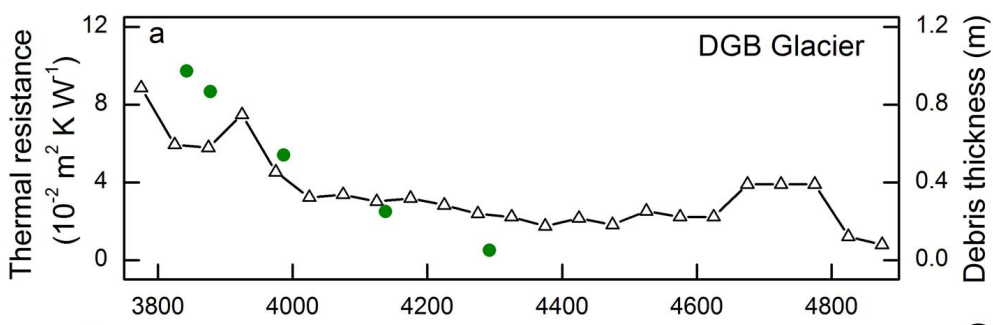

TCD

7, 2413-2453, 2013

Spatial debris-cover effect on the maritime glaciers
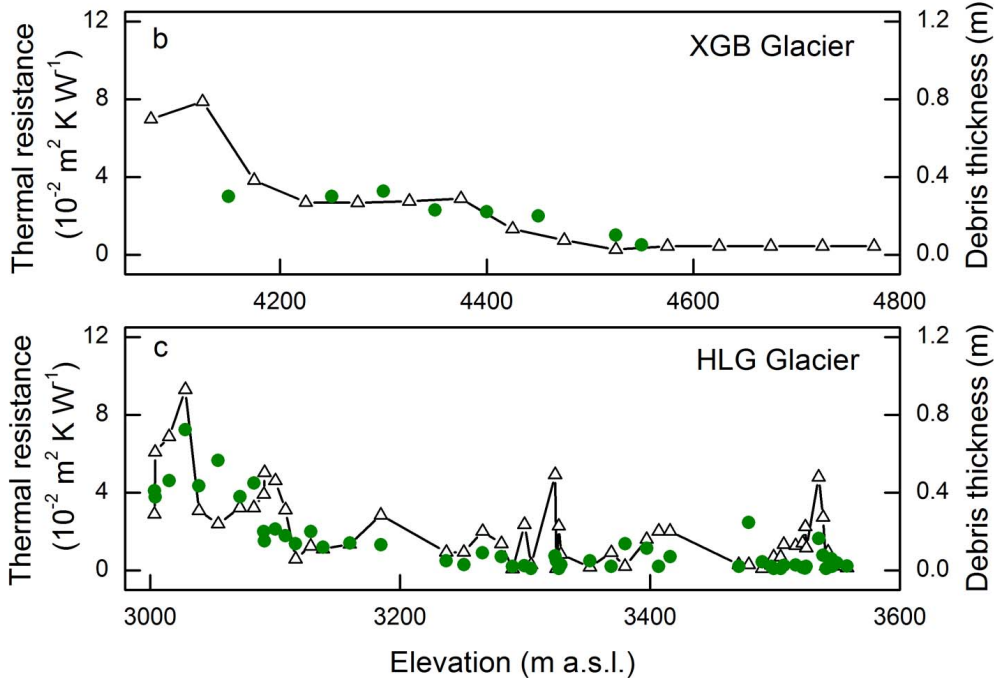

Y. Zhang et al.

Title Page

Abstract

Introduction

Conclusions

References

Tables

Figures

$1<$

DI

4

Back

Close

\section{Full Screen / Esc}

Fig. 3. Comparison of the ground-surveyed debris thicknesses (point) derived from $\mathrm{Li}$ and $\mathrm{Su}$ (1996) and Zhang et al., (2011) and ASTER-derived thermal resistances of debris layers (line) on Dagongba (DGB) (a), Xiaogongba (XGB) (b) and Hailuogou (HLG) (c) glaciers. See Fig. 1

Printer-friendly Version for glacier locations.

Interactive Discussion 

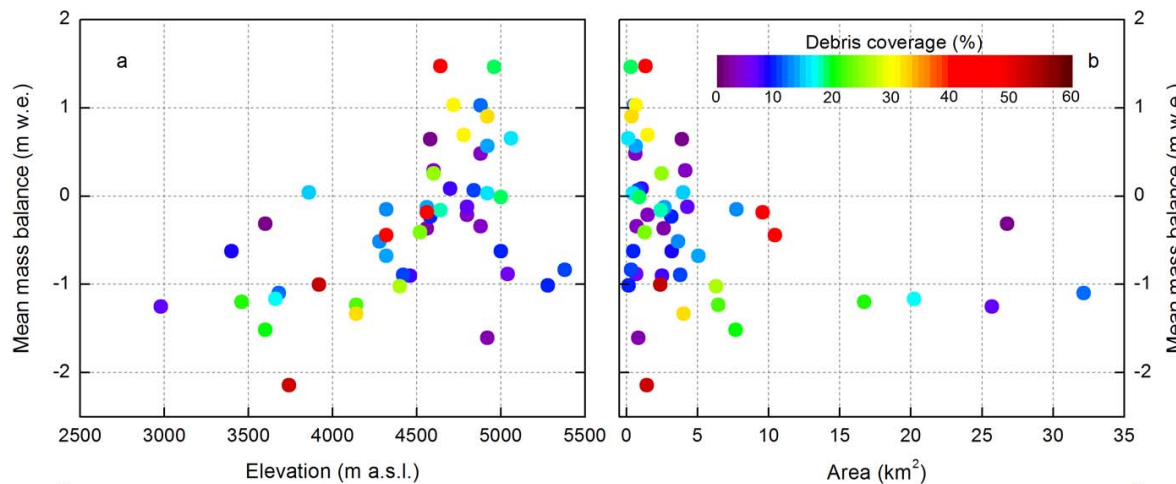

TCD
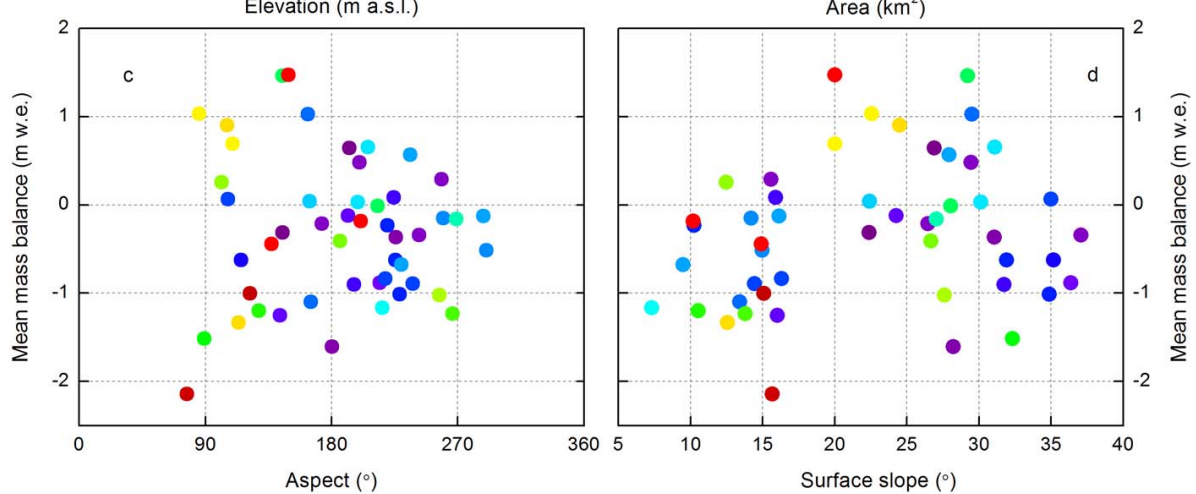

Fig. 4. Scatter plots of mean mass balance of debris-covered glaciers for the period 1998-2007 versus glacier elevation (a), area (b), aspect (c) and surface slope (d), respectively. Markersymbol colors denote the debris-covered proportion of total glacier area; $0(360)^{\circ}, 90^{\circ}, 180^{\circ}$ and $270^{\circ}$ in (c) represent the north, east, south and west, respectively.

Spatial debris-cover effect on the maritime glaciers

Y. Zhang et al.

Title Page

\section{Full Screen / Esc}

Printer-friendly Version

Interactive Discussion 


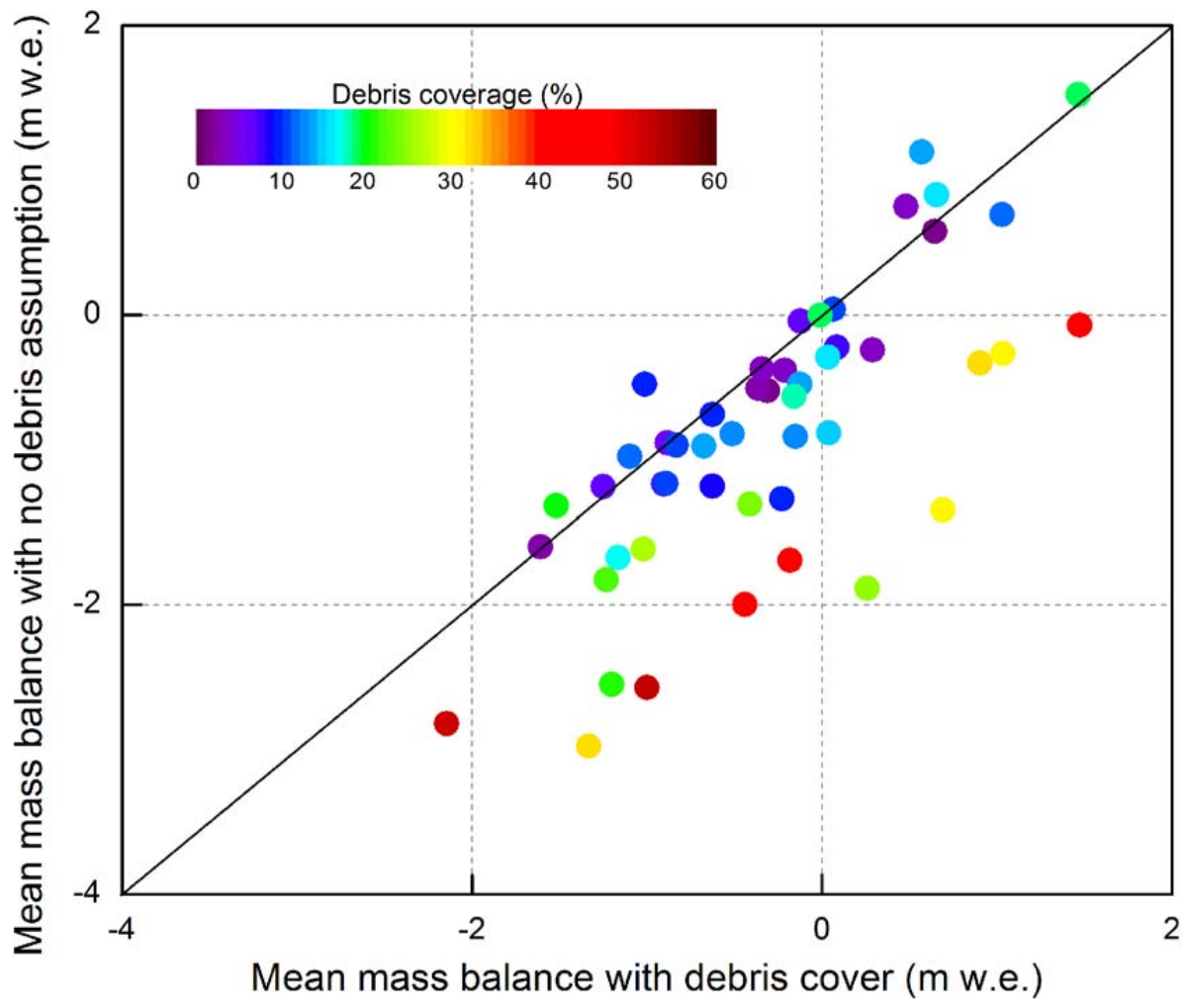

Fig. 5. Comparison of mean mass balance of debris-covered glaciers calculated with the real surface condition and that calculated with the no-debris assumption. Marker-symbol colors denote the debris-covered proportion of total glacier area.
TCD

$7,2413-2453,2013$

Spatial debris-cover effect on the maritime glaciers

Y. Zhang et al.

Title Page
Abstract

Conclusions

Tables

I

4

Back
Introduction

References

Figures

DI

$>$

Close

\section{Full Screen / Esc}

Printer-friendly Version

Interactive Discussion 


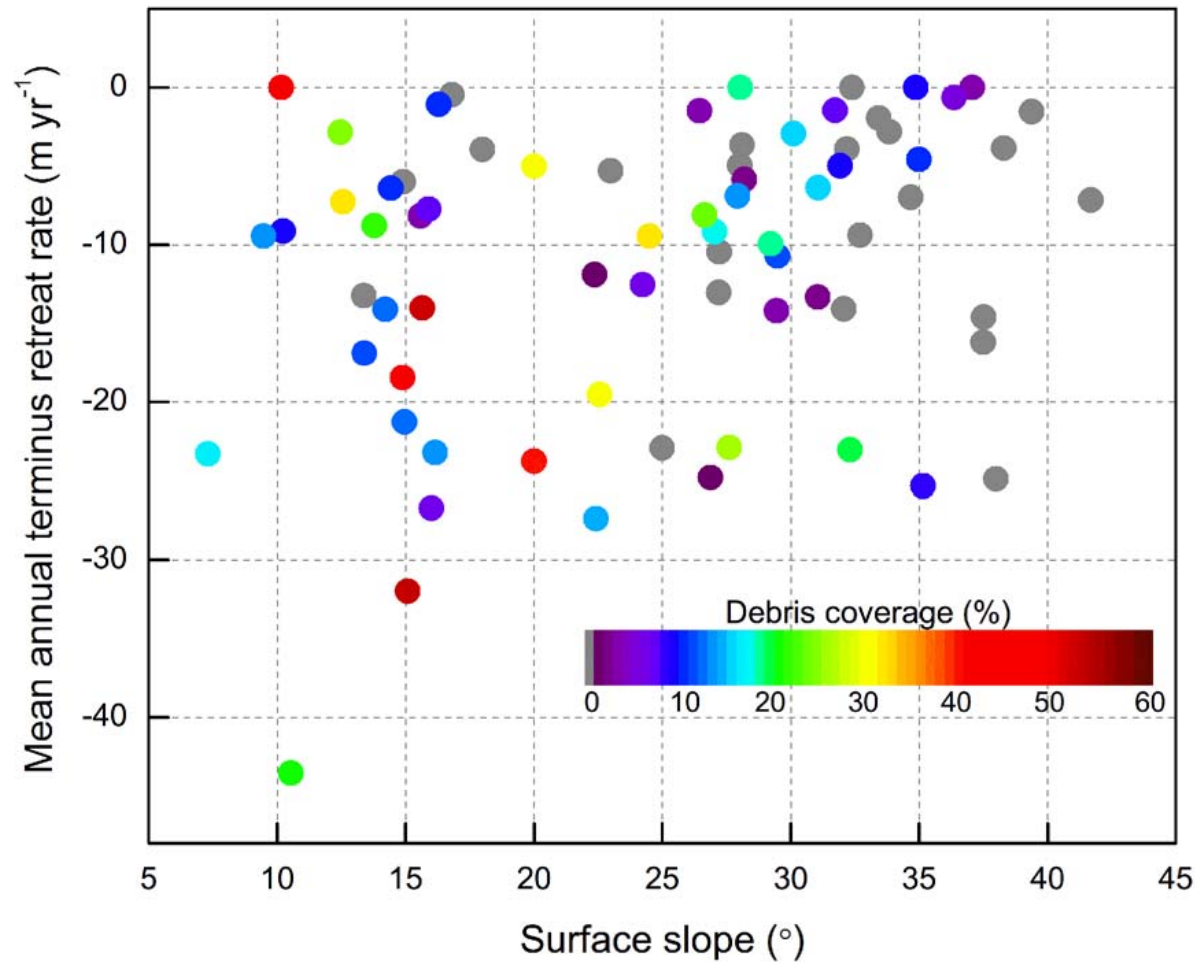

Fig. 6. Scatter plot of mean annual terminus retreat rates versus mean surface slopes of the ablation zones of debris covered and debris-free (grey dots) glaciers. Marker-symbol colors denote the debris-covered proportion of total glacier area.
TCD

$7,2413-2453,2013$

Spatial debris-cover effect on the maritime

glaciers

Y. Zhang et al.

\section{Title Page}

Abstract

Introduction

Conclusions

References

Tables

Figures

14

4

Back

Close

\section{Full Screen / Esc}

Printer-friendly Version

Interactive Discussion 


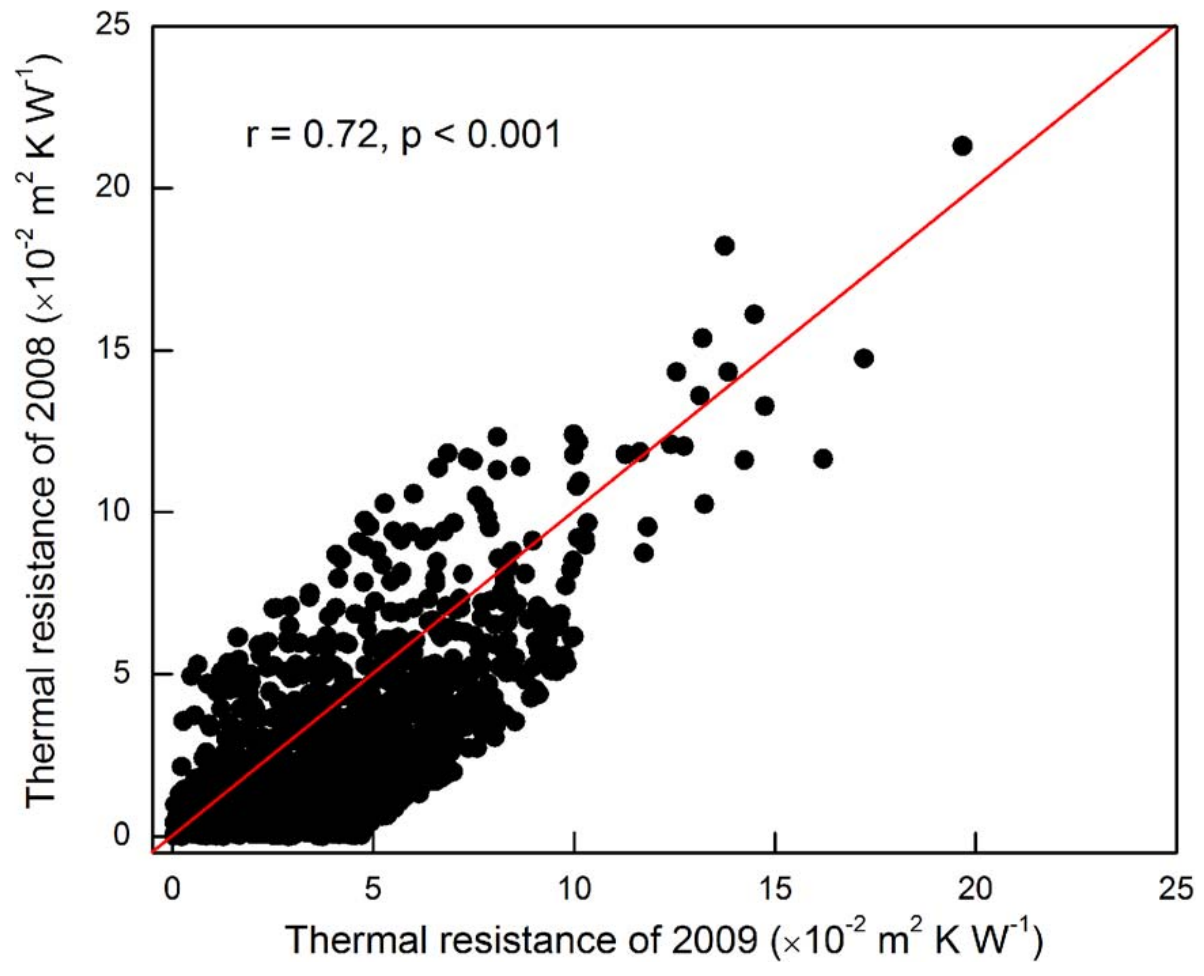

Fig. 7. Comparison of the 2008 and 2009 ASTER-derived thermal resistances at the same pixels on Mount Gongga glaciers. The letters $r$ and $p$ denote the correlation coefficient and significance level, respectively.

\section{TCD}

$7,2413-2453,2013$

Spatial debris-cover effect on the maritime

glaciers

Y. Zhang et al.

\section{Title Page}

\section{Abstract}

Conclusions

Tables

14

Back
Introduction

References

\section{Figures}

$>1$

$>$

Close

\section{Full Screen / Esc}

Printer-friendly Version

Interactive Discussion 


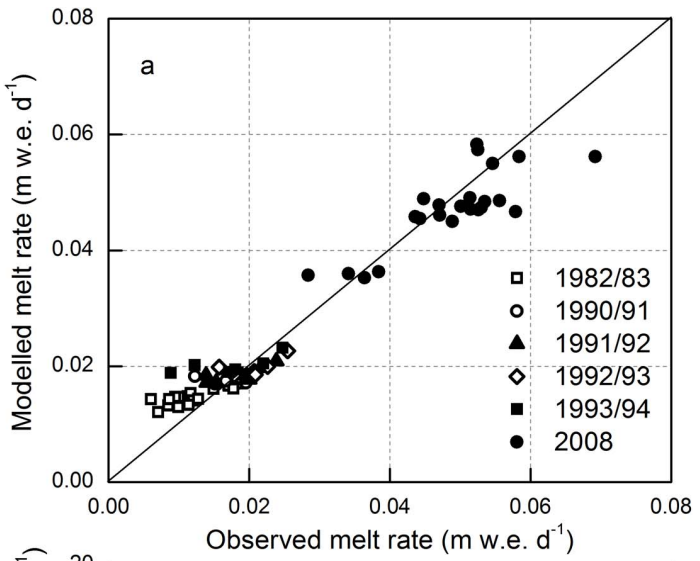

TCD

7, 2413-2453, 2013

Spatial debris-cover effect on the maritime glaciers

Y. Zhang et al.

Title Page

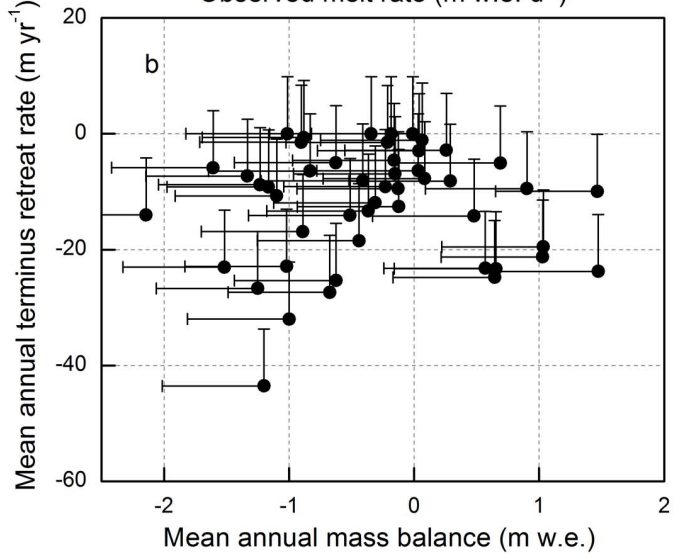

\section{Full Screen / Esc}

Fig. 8. Comparisons of observed and modelled ice melt rate in different periods (a) and mean annual mass balances over the period 1998-2007 and mean annual terminus retreat rates over the period 1966-2009 (b). Error bars indicate the standard deviation. 